\title{
The Effects of Excitatory Amino Acids on Intracellular Calcium in Single Mouse Striatal Neurons in vitro
}

\author{
Shawn N. Murphy, Stanley A. Thayer, and Richard J. Miller \\ Department of Pharmacological and Physiological Sciences, University of Chicago, Chicago, Illinois 60637
}

\begin{abstract}
Using microspectrofluorimetry and the calcium-sensitive dye fura-2, we examined the effect of excitatory amino acids on $\left[\mathrm{Ca}^{2+}\right]_{\mathrm{t}}$ in single striatal neurons in vitro. $\mathbf{N}$-methyl-D-aspartic acid (NMDA) produced rapid increases in $\left[\mathrm{Ca}^{2+}\right]_{i-}$. These were blocked by DL-2-amino-5-phosphonovaleric acid (AP5), by $\mathrm{Mg}^{2+}$, by phencyclidine, and by MK801. The block produced by $\mathbf{M g}^{2+}$ and $\mathbf{M K} 801$ could be relieved by depolarizing cells with veratridine. When external $\mathrm{Ca}^{2+}$ was removed, NMDA no longer increased $\left[\mathrm{Ca}^{2+}\right]_{\mathrm{i}}$. Furthermore, the effects of NMDA were not blocked by concentrations of $\mathrm{La}^{3+}$ that blocked depolarization induced rises in $\left[\mathrm{Ca}^{2+}\right]_{i}$. Substitution of $\mathrm{Na}^{+}$。 by $\mathrm{Li}^{+}$did not block the effects of NMDA. Concentrations of L-glutamate $\geq 10^{-6} \mathrm{M}$ also increased $\left[\mathrm{Ca}^{2+}\right]_{\mathrm{i}}$. The effects of moderate concentrations of glutamate were blocked by AP5 but not by $\mathrm{La}^{3+}$ or by substitution of $\mathrm{Na}^{+}$by $\mathrm{Li}^{+}$. The effects of glutamate were blocked by removal of external $\mathrm{Ca}^{2+}$ but were not blocked by concentrations of $\mathrm{Mg}^{2+}$ or $\mathrm{MK801}$ that completely blocked the effects of NMDA. The glutamate analogs kainic acid (KA) and quisqualic acid also increased

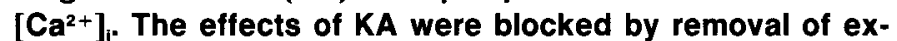
ternal $\mathrm{Ca}^{2+}$ but not by $\mathrm{La}^{3+}, \mathrm{Mg}^{2+}, \mathrm{MK801}$, or replacement of $\mathrm{Na}^{+}$by $\mathrm{Li}^{+}$. Although AP5 was able to block the effects of KA partially, very high concentrations were required. These results may be explained by considering the properties of glutamate-receptor-linked ionophores. Excitatory amino acid induced increases in $\left[\mathrm{Ca}^{2+}\right]_{i}$ are consistent with the possibility that $\mathrm{Ca}^{2+}$ mediates excitatory amino acid induced neuronal degeneration.
\end{abstract}

L-Glutamate or a similar molecule is probably the most widely used excitatory neurotransmitter in the brain. The electrophysiological effects of glutamate are complex, as it is hypothesized to act as an agonist at more than one type of receptor site (Foster and Fagg, 1984; Mayer and Westbrook, 1984, 1987a; O'Brien and Fischbach, 1986). It is thought that these diverse receptor types allow glutamate to transmit both rapid excitatory signals and also other forms of transsynaptic information that may result in the long-term alteration of synaptic contacts (Lynch and Baudry, 1984). In addition to its physiological effects, it has

\footnotetext{
Received Mar. 18, 1987; revised May 21, 1987; accepted June 5, 1987.

We thank R. M. Demuth for histochemical staining of the cultures. Supported by PHS Grants DA-02121, DA-02575, and MH-40165 amd by grants from Miles Pharmaceuticals and the University of Chicago Brain Research Institute. S. N. Murphy was supported by GM-07151. S. A. Thayer was supported by PHS NS08009. R.J.M. was a Guggenheim Fellow.

Correspondence should be addressed to Prof. Richard J. Miller, Ph.D., Department of Pharmacological and Physiological Sciences, University of Chicago, 947 East 58th Street, Chicago, IL 60637.

Copyright (C) 1987 Society for Neuroscience $0270-6474 / 87 / 124145-14 \$ 02.00 / 0$
}

also often been observed that administration of glutamate or its structural analogs directly into the brain is highly toxic and results in the destruction of neurons whose cell bodies are close to the site of administration (Olney, 1969; Schwarcz et al., 1984; Rothman, 1985). Apart from being a useful lesioning technique, such effects may be extremely important in certain pathological conditions. For example, it is thought that the neuronal degeneration associated with conditions such as cerebral ischemia epilepsy, Alzheimer's disease, and Huntington's chorea may result from the release of abnormal quantities of glutamate-like agonists in situ under certain conditions (Schwarcz et al., 1984). Neuronal death can also be observed following the addition of glutamate-like agonists to nerve cells in vitro (Rothman, 1985; Hajos et al., 1986; Olney, 1986; Choi et al., 1987a, b). It is clearly important to elucidate the mechanisms underlying the toxic effects of excitatory amino acids ("excitotoxicity") and their relationship to the normal physiological actions of these substances.

One major hypothesis suggests that excitotoxicity may be due to agonist-induced $\mathrm{Ca}^{2+}$ overloading in neurons (Garthwaite and Garthwaite, 1986a; Garthwaite et al., 1986; Hajos et al., 1986; Choi et al., 1987). The toxic effects of abnormally high levels of free $\mathrm{Ca}^{2+},\left[\mathrm{Ca}^{2+}\right]_{i}$, would be analogous to similar toxic effects of high $\left[\mathrm{Ca}^{2+}\right]_{\text {i }}$ associated with the atrophy of cardiac muscle cells (Shen and Jennings, 1972). In support of this idea, several studies have demonstrated that neurons can be protected from excitotoxic effects by reducing $\left[\mathrm{Ca}^{2+}\right]_{0}$ (Choi, 1985, 1987; Garthwaite and Garthwaite, 1986a; Garthwaite et al., 1986; Hajos et al., 1986), although this is not true in every case (Price et al., 1985; Rothman, 1985; Kleinschmidt et al., 1986). Furthermore, administration of excilatory amino acids directly into the brain or to brain slices appears to lead to an influx of $\mathrm{Ca}^{2+}$ as assessed by an increase in $\mathrm{Ca}^{2+}$ uptake (Ichida et al., 1982; Retz et al., 1982; Berdichevsky et al., 1983; Retz and Coyle, 1984; Harris, 1985; Pastuszko and Wilson, 1985; Wroblewski et al., 1985, 1987; Crowder et al., 1986; Garthwaite and Garthwaite, 1986b; Lazarewicz et al., 1986; Riveros and Orrego, 1986) or a decrease in $\left[\mathrm{Ca}^{2+}\right]_{0}$ measured with $\mathrm{Ca}^{2+}$-sensitive microelectrodes or by other means (Heinemann and Pumain, 1980, 1981; Marciani et al., 1982; Buhrle and Sonnhof, 1983; Zanotto and Heinemann, 1983; Korf and Postema, 1984; Pumain and Heinemann, 1985; Ashton et al., 1986; Hamon and Heinemann, 1986; Sakamoto et al., 1986). Unfortunately, however, the cellular elements responsible for such effects are not usually precisely identified.

The mechanisms by which glutamate increases $\left[\mathrm{Ca}^{2+}\right]_{\mathrm{i}}$ are also unclear. The best-defined receptor for glutamate is characterized by the agonist effects of the amino acid, $N$-methyl-D- 
aspartate (NMDA). The ionophore activated by such agonists appears to be permeable to monovalent cations such as $\mathrm{Na}^{+}$ (Mayer et al., 1984; Nowak et al., 1984; Mayer and Westbrook, 1985b, 1987a; Jahr and Stevens, 1987) and is also appreciably permeable to $\mathrm{Ca}^{2+}$ (Mayer and Westbrook, 1985a, 1986; Ascher and Nowak, 1986; MacDermott et al., 1986; Jahr and Stevens, 1987; Mayer et al., 1987b). Interestingly, in normal physiological medium, $I-V$ curves in the presence of NMDA cxhibit a region of negative slope conductance at membrane potentials between about -30 to $-80 \mathrm{mV}$ (Mayer and Westbrook, 1984, 1987a; Westbrook and Mayer, 1984; O'Brien and Fischbach, 1986). The reason for this is unusual. Rather than possessing voltage-dependent gating properties per se, the NMDA-linked ionophore is blocked in a voltage-dependent manner by low concentrations of $\mathrm{Mg}^{2+}$ (Crunelli and Mayer, 1984; Mayer et al., 1984; Nowak et al., 1984; Mayer and Westbrook, 1987a). This block is relieved if the cell depolarizes. In the absence of $\mathrm{Mg}^{2+}$, NMDA-induced currents increase as the membrane is hyperpolarized. Glutamate also acts at other non-NMDA receptors (Foster and Fagg, 1984). Such receptors are typified by the actions of agonists such as kainic acid (KA) or quisqualic acid (QA). Cellular depolarization resulting from the action of these agonists is associated with an increase in membrane conductance (Mayer and Westbrook, 1984, 1987b; Nowak and Ascher, 1984; Westbrook and Mayer, 1984; O'Brien and Fischbach, 1986). Under voltage-clamp conditions the currents induced by $\mathrm{KA}$ increase with increasing hyperpolarization. Thus, the ionophore linked to the $\mathrm{KA}$ receptor does not exhibit a voltage-dependent block by $\mathrm{Mg}^{2+}$. Furthermore, in contradistinction to the NMDA-linked channel, this ionophore is reported to be virtually impermeable to $\mathrm{Ca}^{2+}$ (MacDermott et al., 1986, Mayer et al., 1987). The exact number of non-NMDAlinked glutamate receptor types is unclear at this point.

One area of the CNS in which the normal and toxic effects of excitatory amino acids have been well studied is the striatum (Nowak and Ascher, 1984, 1985; Nowak et al., 1984; Ascher and Nowak, 1986; Beal et al., 1986; Silverstein et al., 1986). Recently we have developed a technique for the measurement of changes in $\left[\mathrm{Ca}^{2+}\right]_{\mathrm{i}}$ in single neurons in primary culture. In the present series of experiments, we have examined the effects of NMDA and non-NMDA receptor agonists on $\left[\mathrm{Ca}^{2+}\right]_{i}$ in single striatal neurons. We find that both types of glutamate agonists produce large increases in $\left[\mathrm{Ca}^{2+}\right]_{\mathrm{i}}$. We have also attempted to elucidate the mechanisms by which these effects are produced.

\section{Materials and Methods}

Cell culture. Neurons were cultured as described in Thayer et al. (1986). Briefly, striatal cells were dissected from mice embryos (C57BL/6J) on day E14. The cells were dissociated and grown as monolayer cultures on glass coverslips coated with polylysine and laminin. Standard cultures were grown at a density of 1200 cells $/ \mathrm{mm}^{2}$. Cells were used after $11 \mathrm{~d}$ in culture, at which time the effects of all agonists were maximal (unpublished observations).

All measurements were made on single cells. It was important to distinguish neuronal cells from glial cells. Most glial cells were distinguishable as large flat cells that covered the coverslip, and neurons could be distinguished on morphological grounds (Panula et al., 1979). In the first 120 cells used, each experiment was terminated by raising $\left[\mathrm{K}^{+}\right]_{\mathrm{o}}$ to $50 \mathrm{~mm}$ in order to investigate the presence of voltage-sensitive $\mathrm{Ca}^{2+}$ channels. We have found that glial cells respond weakly $\left(\Delta\left[\mathrm{Ca}^{2+}\right]_{i}<\right.$ $100 \mathrm{~nm}$ ) or not at all to this depolarizing stimulation; in contrast, neurons nearly always raise cytosolic calcium $>200 \mathrm{~nm}$ (Thayer et al., 1986). After testing 120 cells and obtaining 119 positive results, the test was no longer considered necessary.
Measurement of $\left[\mathrm{Ca}^{2+}\right]_{i}$. Cytosolic free $\mathrm{Ca}^{2+}$ was determined by using a microspectrofluorimeter, which has been described previously (Perney et al., 1984; Thayer et al., 1986) to monitor the $\mathrm{Ca}^{2+}$-sensitive, fluorescent chelator, fura- 2 . Neurons were loaded with the dye by incubation in $5 \mu \mathrm{M}$ fura-2 acetoxymethyl ester, which is membrane permeant, for $1 \mathrm{hr}$ at $37^{\circ} \mathrm{C}$ in HEPES-buffered Hanks' balanced salt solution, $\mathrm{pH}$ 7.45. During the loading incubation, the dye ester is hydrolyzed by cytosolic esterases to the membrane-impermeant polycarboxylate anion that is fura-2. Following the incubation, the cells were washed twice in HEPES-Hanks' solution and incubated for an additional $15 \mathrm{~min}$. Complete hydrolysis of the fura- 2 ester to fura- 2 was confirmed by comparing excitation spectra run on individual dye-loaded cells (Fig. 1A). Cells were treated with $10 \mu \mathrm{M}$ ionomycin to raise $\left[\mathrm{Ca}^{2+}\right]_{i}>30 \mu \mathrm{M}$ (where the calcium chelator is saturated). EGTA, $20 \mathrm{mM}$, was then added to the standard HEPES-Hanks solution, lowering the $\left[\mathrm{Ca}^{2+}\right]_{0}$ to very low levels. Notice that the spectrum of the fura-2 ester peaked at wavelengths slightly greater than $380 \mathrm{~nm}$ and was $\mathrm{Ca}^{2+}$ insensitive. Spectra of ionomycin-treated, dye-loaded cells peaked at less than $350 \mathrm{~nm}$, as expected for the fura-2-free acid in the presence of $\mathrm{Ca}^{2+}$, and fluoresced at an intensity near background ( $<10 \%$ of intensity at $340 \mathrm{~nm}$ ) at wavelengths greater than $380 \mathrm{~nm}$, indicating that no significant concentration of the dye ester was present in these loaded and washed striatal neurons.

The coverslips containing the loaded and washed cells were mounted in a flow-through chamber for viewing. The chamber consisted of a 3 $\mathrm{ml}$ stainless-steel-lined well, surmounted by a rubber O-ring, against which the inverted coverslip was sealed by pressure. The bottom of the well was covered by a Plexiglas plate for substage illumination to localize cells. The temperature in the well was monitored by a thermocouple probe and maintained at $37^{\circ} \mathrm{C}$ by circulating warm water in a separate surrounding cavity. The cells were usually maintained in a bath of HEPES-buffered Hanks' balanced salt solution ( $\mathrm{pH} 7.45$ ), which contains (in mM): $\mathrm{NaCl}, 137 ; \mathrm{KCl}, 5.4 ; \mathrm{MgSO}_{4}, 0.41 ; \mathrm{MgCl}_{2}, 0.49 ; \mathrm{CaCl}_{2}$, 1.26; $\mathrm{KH}_{2} \mathrm{PO}_{4}, 0.44 ; \mathrm{Na}_{2} \mathrm{HPO}_{4} \cdot 7 \mathrm{H}_{2} \mathrm{O}, 0.64 ; \mathrm{NaHCO}_{3}, 3 ;$ glucose, 5.5; HEPES, 20. Exceptions were $\mathbf{M g}^{2+}$-free experiments, in which $\mathbf{M g}^{2+}$ was eliminated from the medium; $\mathrm{La}^{3+}$ experiments, where all anions were replaced with an equal normal of $\mathrm{Cl}^{-} ; \mathrm{Na}^{+}$-free experiments in which equal molar amounts of $\mathrm{Li}^{+}$or $N$-methyl-D-glucamine (NMDG) was substituted; and $\mathrm{Ca}^{2+}$-free experiments, where $\mathrm{Ca}^{2+}$ was removed and $20 \mu \mathrm{M}$ EGTA added to the solution. All washing was done using a flow rate of $3 \mathrm{ml} / \mathrm{min}$.

Fura-2 fluorescence from individual cells was monitored with a microspectrofluorimeter operating in the epi-illumination mode. Light from a xenon arc lamp was passed through a double-grating monochromator to the Ploem illuminator of a Leitz Orthoplan microscope. A $\times 54$ fluorite objective was used, and a rectangular diaphragm was set to limit fluorescence measurements to individual cells. The fluorescence emission was analyzed by a second double-grating monochromator and a Leitz MPV I photomultiplier tube coupled to a Princeton Applied Research photon counter. Each cell was alternately excited with 340 and $380 \mathrm{~nm}$ light every $30 \mathrm{sec}$. Emissions were collected every second with the photomultiplier tube, digitized with the photon counter, and stored in the memory of an LSI 11/03 minicomputer. The $1 \mathrm{sec}$ readings were usually averaged over each 30 sec time period, and a ratio was calculated for every $30 \mathrm{sec}$. This allowed free cytosolic calcium concentrations to be obtained every $30 \mathrm{sec}$ using the calibration curve shown in Figure 1B. The fura-2 fluorescence intensity measured at $340 \mathrm{~nm}$ increases upon binding $\mathrm{Ca}^{2+}$, whereas the $380 \mathrm{~nm}$ intensity reflects dye that has not bound $\mathrm{Ca}^{2+}$; therefore, the ratio of these 2 measurements is related to the free $\mathrm{Ca}^{2+}$ concentration in a manner that is not dependent on optical pathlength, dye concentration, or dye bleaching. A standard curve was determined for the fura-2 pentapotassium salt in calibration buffer ( $\mathrm{pH} 7.05,37^{\circ} \mathrm{C}$ - which contains (in mM): $\mathrm{KCl}, 120 ; \mathrm{NaCl}, 5$; $\mathrm{KH}_{2} \mathrm{CO}_{4}, 1 ; \mathrm{NaHCO}_{3}, 5$; HEPES, 20; EGTA, 20)-containing CaEGTA and $K_{2}$ EGTA in ratios that were calculated using the stability constant $3.06 \times 10^{6} \mathrm{M}^{-1}$ (Bers, 1982) to give $\mathrm{Ca}^{2+}$ concentrations ranging from 0 to 1000 nm. In these buffers we assume that the dye behaves like the intracellular dye. The standard curve was fit with the equation $K](R-$ $\left.R_{\min }\right) /\left(R_{\max }-R\right)$ ], in which $K$ is a calibration constant, $R$ is the $340 /$ $380 \mathrm{~nm}$ fluorescence ratio, and $R_{\min }$ and $R_{\max }$ are the ratios in the absence of calcium and in saturating concentrations of calcium, respectively.

Experimental procedure. Cells were mounted in the microspectrofluorimeter as shown in Figure 1C. Note the image of the back-lit photomultiplier diaphragm, which defines the area from which photon counts were recorded. $\left[\mathrm{Ca}^{2+}\right]_{i}$ was measured for $2 \mathrm{~min}$ prior to agonist application; neurons with resting $\left[\mathrm{Ca}^{2+}\right]_{i}$ above $120 \mathrm{~nm}$ or whose resting 
A

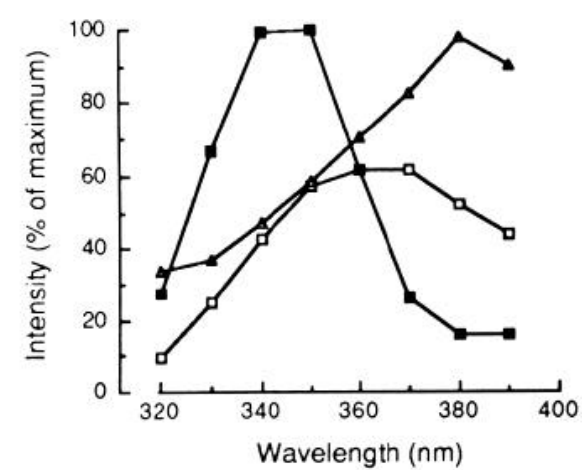

B

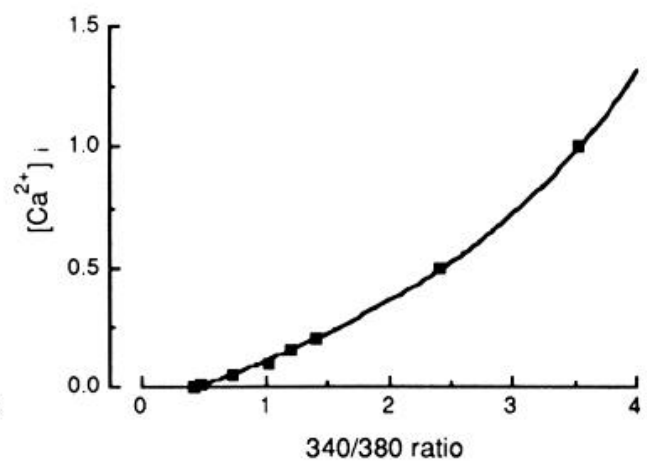

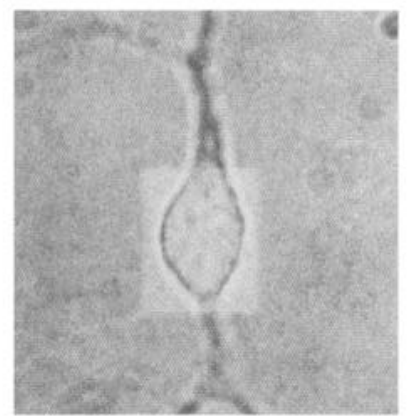

Figure 1. Fura-2 spectral and calibration curves. Excitation spectra were run on a single striatal neuron $(A)$ treated with $1 \mu \mathrm{M}$ ionomycin in the presence of $1.2 \mathrm{~mm} \mathrm{Ca}^{2+}$ (solid squares) followed by 20 mM EGTA (open squares). Also shown is the spectrum of fura- 2 acetoxymethyl ester determined in the same chamber (open triangles). The spectral shift of fura-2 upon binding calcium enabled the determination of the calibration curve shown in $B$, where the $Y$-axis is $\mu$ moles/liter of calcium in cytosolic buffer. $C$, Photomicrograph of a striatal neuron mounted in the microspectrofluorimeter.

$\left[\mathrm{Ca}^{2+}\right]_{\mathrm{i}}$ fluctuated more than $\pm 20 \mathrm{nM}$ were not used. These conditions occurred rarely and seemed to be related to poor cell viability. Agonists and antagonists were applied with rapid injections into the chamber using Hamilton syringes. Similar volumes of solvents were often injected prior to agonist application to test for injection artifacts. All antagonists were applied $3 \mathrm{~min}$ before agonist application, except for MK801, which was applied $1 \mathrm{hr}$ before agonist application. Desensitization experiments were always performed with 4 min of wash time, followed by a minute of wait time (allowing a stable basal $\left[\mathrm{Ca}^{2+}\right]_{i}$ reading to be taken) before the second agonist application. Those cells whose $\left[\mathrm{Ca}^{2+}\right]_{i}$ did not return to within $40 \mathrm{nM}$ of its preagonist value were not used.

Calculations. The dose-response curves of all 3 agonists tested showed a strong concentration dependence and were fit with the equation $\left[\mathrm{Ca}^{2+}\right]_{\mathrm{i}}=$ $K_{1}\left(K_{2} A+2 K_{2} K_{3} A^{2}\right) /\left(1+K_{2} A+K_{2} K_{3} A^{2}\right)$, where $A$ is the concentration of agonist and $K_{1}, K_{2}, K_{3}$ are constants that are varied to provide the best fit. This classical cooperative binding equation allowed for the steep dose dependence to be fit satisfactorily for a more accurate determination of $\mathrm{EC}_{50}$ 's. Statistical tests on experiments where the effects of antagonists and ion substitution were tested were paired with control experiments of that same day. The SE shown on the control dose in the figures represents the largest SE of any controls paired with experiments of that figure. Illustrated error bars represent SEs.

Materials. MK801 was a kind gift of Drs. L. Iversen and G. Woodruff, Merck Sharp \& Dohme, UK. PCP was obtained from the National Institutes of Health. Dioxadrol isomers were gifts of S. R. Zukin. GAMS was a gift of J. Ferkany, NOVA, USA. Fura-2 was purchased from Molecular Probes Inc., Eugene, OR. All other drugs were purchased from Sigma.

\section{Results}

\section{Cell culture}

Striatal neurons in primary culture were routinely used between day 11 and 21 unless specified. Although the magnitude of the excitatory amino acid-induced changes in $\left[\mathrm{Ca}^{2+}\right]_{\mathrm{i}}$ we observed did differ from cell to cell, we did not find any obvious subcategories of neurons that could be defined according to response size. Resting $\left[\mathrm{Ca}^{2+}\right]_{\text {, }}$ 's were $56 \pm 27 \mathrm{~nm}$ (mean $\pm \mathrm{SD}$ ). It is our impression that virtually all neurons in these striatal cultures will respond to excitatory amino acids, although using other criteria, the cultures are quite heterogeneous, as might be expected. Thus, populations of neurons stained positively with antisera against GABA, choline acetyltransferase, substance $P$, methionine enkephalin, and somatostatin. Of these the GABAcontaining cells were by far in greatest abundance, as in the mature striatum (Panula et al., 1980). Experiments were carried out in 550 single striatal neurons, selected as discussed in Materials and Methods.

\section{Action of NMDA}

When NMDA $\left(10^{-6}-10^{-3} \mathrm{M}\right)$ was added to cells in normal physiological medium, only very small increases in $\left[\mathrm{Ca}^{2+}\right]_{i}$ were observed (Fig. 2). However, the situation altered dramatically when $\mathrm{Mg}^{2+}$ was removed from the medium. Now, addition of NMDA at concentrations above $3 \times 10^{-6} \mathrm{M}$ produced a rapid increase in $\left[\mathrm{Ca}^{2+}\right]_{\mathrm{i}}$ (Fig. 2). Maximal effects of NMDA were observed at or above $3 \times 10^{-5} \mathrm{M}$. If NMDA remained in the incubation medium, $\left[\mathrm{Ca}^{2+}\right]_{\mathrm{i}}$ tended to remain elevated over several minutes, sometimes declining slowly (Fig. 2). If NMDA was washed out, $\left[\mathrm{Ca}^{2+}\right]_{i}$ tended to decline more rapidly, although the rate of decline varied considerably from cell to cell. The response to $10 \mu \mathrm{M}$ NMDA had a tendency to desensitize. Thus, following an initial response and washout, a second challenge with the same concentration of agonist produced a considerably attenuated response (Fig. 2). The effects of NMDA were blocked by prior addition of the putative competitive NMDA receptor blocker DL-2-amino-5-phosphonovaleric acid (AP5) (Fig. 3). Other classes of drugs have been reported to block the effects of NMDA by interacting with the receptor-linked ionophore rather than by competing with NMDA for its recognition site. These include PCP-like compounds (Anis et al., 1983; Honey et al., 1985). As can be seen from Figure 3, PCP caused a dosedependent, noncompetitive decrease in the effect of NMDA $\left(\mathrm{IC}_{50}=2 \times 10^{-7} \mathrm{M}\right)$. The block produced by these drugs was stereospecific. Thus, the $\mathrm{D}$-isomer of the enantiomeric pair dexoxadrol and levoxadrol was a potent blocker, whereas the L-isomer was ineffective at $2 \times 10^{-7} \mathrm{M}$ (Fig. 3). Furthermore, the newly described compound MK-801, which also appears to act at the same site on the ionophore as PCP (Wong et al., 1986), also powerfully blocked the effect of NMDA (Fig. 3).

The effects of both $\mathrm{Mg}^{2+}$ and MK-801 appeared to be voltage dependent (Fig. 4). Normally, in the presence of $\mathrm{Mg}^{2+}\left(9 \times 10^{-4}\right.$ M) NMDA produced no effect (vide supra). We added low concentrations of veratridine $\left(5 \times 10^{-7} \mathrm{M}\right)$ to cells in order to depolarize them. As shown in Figure 5, this concentration of veratridine was insufficient to depolarize cells enough to evoke $\mathrm{Ca}^{2+}$ entry through voltage-sensitive $\mathrm{Ca}^{2+}$ channels. However, after adding veratridine, NMDA produced large increases in $\left[\mathrm{Ca}^{2+}\right]_{\mathrm{i}}$ even in the presence of $\mathrm{Mg}^{2+}$. In a similar paradigm it can be seen that veratridine also relieved the block of the NMDA 


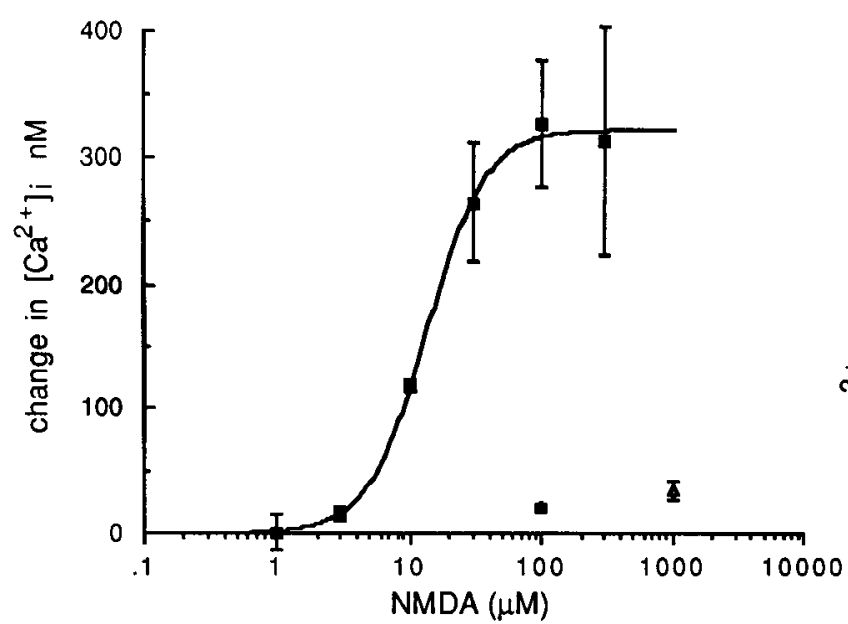

Figure 2. NMDA-induced increases in $\left[\mathrm{CA}^{2+}\right]_{\mathrm{i}}$. In $\mathrm{Mg}^{2+}$-free buffer, NMDA stimulated a rise in $\left[\mathrm{Ca}^{2+}\right]_{i}$ in a dosedependent manner as shown in $A$ (solid squares). In the presence of $0.9 \mathrm{~mm}$ $\mathrm{Mg}^{2+}$, the response was essentially blocked (open triangles). A curve was fit through the $\mathbf{M g}^{2+}$-free points using the equation described in Materials and Methods and the parameters $K_{1}=$ $161.6, K_{2}=0.0022, K_{3}=2.52(4<n<$ 10 for all points). $B$, Using the paradigm described in Materials and Methods, the second response $\left(\mathrm{Mg}^{2+}\right.$-free media) was attenuated by $91 \%(n=5)$. $C$. Typical response as well as an attenuated second response. $D$, The reversible nature of the $\mathrm{Mg}^{2+}$ block is shown in the trace. The asterisk designates significantly different from control with $p<0.01$.
C

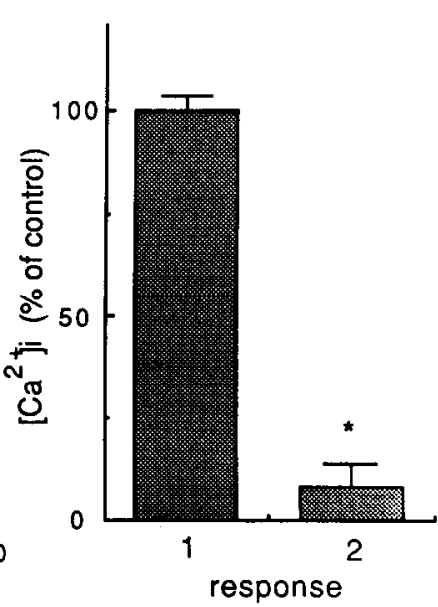

D
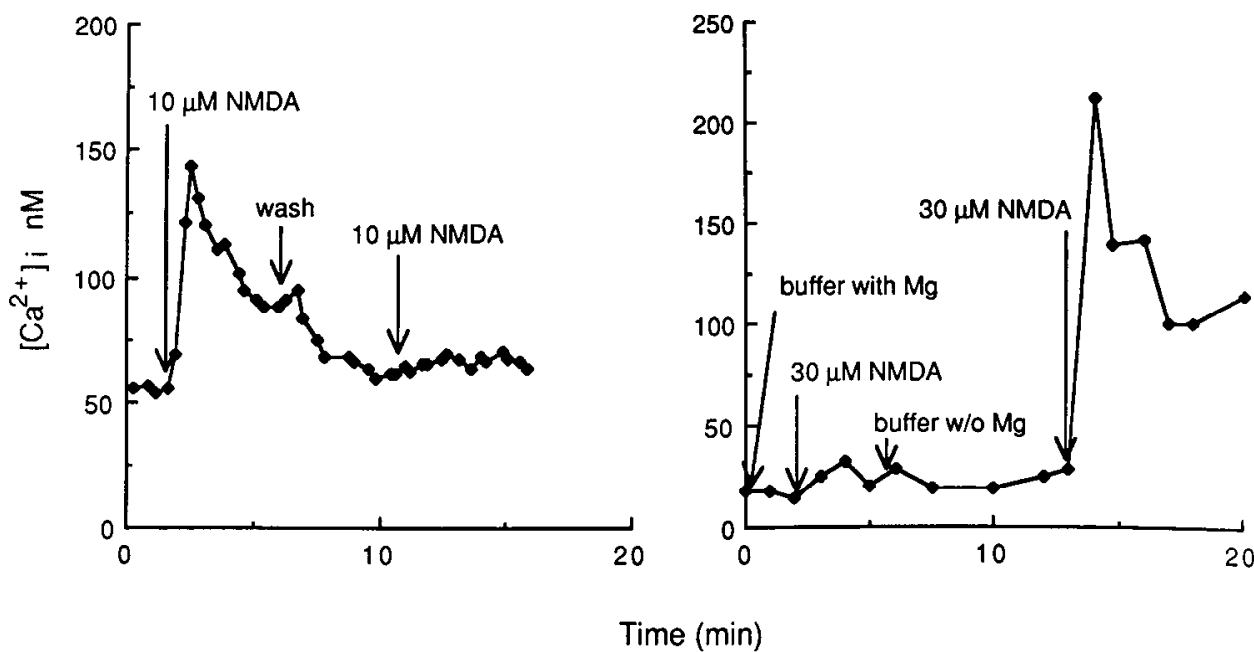

effect produced by MK801, although the NMDA responses were somewhat attenuated over time. In contrast, the blocking effects of AP5 were not voltage dependent and were still manifest in the presence of veratridine.

We attempted to elucidate the mechanism of the NMDAinduced increase in $\left[\mathrm{Ca}^{2+}\right]_{\mathrm{i}}$. Figure 5 presents the various possibilities that we considered. The simplest explanation is that $\mathrm{Ca}^{2+}$ enters through the NMDA-receptor-linked ionophore. A second possibility is that $\mathrm{Na}^{+}$and $\mathrm{Ca}^{2+}$ enter via this ionophore, depolarizing the cell and opening voltage-sensitive $\mathrm{Ca}^{2+}$ channels. The major route of $\mathrm{Ca}^{2+}$ entry might then be through such channels. A further possibility is that $\mathrm{Na}^{+}$entering through the ionophore reduces the gradient for $\mathrm{Na}^{+} / \mathrm{Ca}^{2+}$ exchange. Calcium may enter by the exchanger operating in reverse or calcium may accumulate with the exchanger unavailable for extrusion of calcium that may leak into the cell. It is also possible that the increase in $\left[\mathrm{Ca}^{2+}\right]_{i}$ represents mobilization of intracellular bound $\mathrm{Ca}^{2+}$ stores using an inositol trisphosphate $\left(\mathrm{IP}_{3}\right)$-linked mechanism and does not depend on $\mathrm{Ca}^{2+}$ entry at all. Furthermore, entry of a small amount of $\mathrm{Ca}^{2+}$ might be necessary, and this could trigger the further release of $\mathrm{Ca}^{2+}$ from intracellular stores. Such $\mathrm{Ca}^{2+}$-triggered $\mathrm{Ca}^{2+}$ release mechanisms are known to exist in skeletal and cardiac muscle for example, and they may also exist in peripheral neurons (MacDermott and Weight, 1982; Smith et al., 1983; Neering and McBurney, 1984).

Figure 6 shows that when $\left[\mathrm{Ca}^{2+}\right]_{0}$ was completely removed, NMDA was unable to increase $\left[\mathrm{Ca}^{2+}\right]_{\mathrm{i}}$. Thus, the cffect of NMDA was dependent on the influx of $\mathrm{Ca}^{2+}$. We attempted to assess the role of $\mathrm{Ca}^{2+}$-induced $\mathrm{Ca}^{2+}$ release by examining the effects of methylxanthines. Intracellular $\mathrm{Ca}^{2+}$ stores that participate in this type of process are normally sensitive to the actions of high concentrations of caffeine or theophylline (MacDermott and Weight, 1982; Smith et al., 1983; Neering and McBurney, 1984; Saida and Van Breemen, 1984). Theophylline, $10 \mathrm{~mm}$, evoked a slow sustained increase in $\left[\mathrm{Ca}^{2+}\right]_{\mathrm{i}}$. However, the methylxanthine was found to be ineffective when $\left[\mathrm{Ca}^{2+}\right]_{0}$ was lowered. Thus, in these cells the rise in $\left[\mathrm{Ca}^{2+}\right]_{\mathrm{i}}$ provoked by theophylline seems to be the result of increased $\mathrm{Ca}^{2+}$ permeability rather than mobilization of intracellular bound $\mathrm{Ca}^{2+}$ stores. It therefore seems unlikely that $\mathrm{Ca}^{2+}$-induced $\mathrm{Ca}^{2+}$ release operates in these central neurons. However, we have not systematically investigated this point, and so it remains possible that the rise in $\left[\mathrm{Ca}^{2+}\right]_{i}$ is amplified in this fashion to some extent.

It is important to try and distinguish $\mathrm{Ca}^{2+}$ entry through ag- 
A

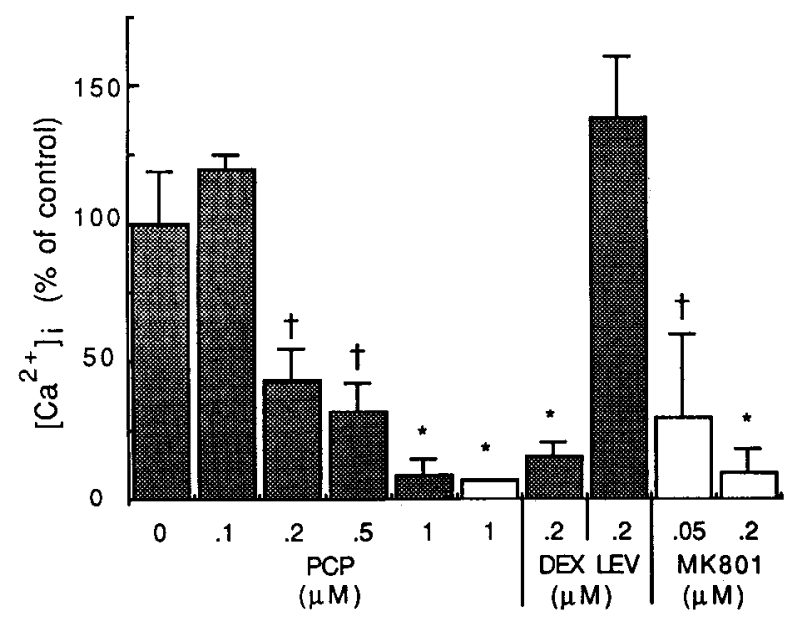

onist-regulated and voltage-sensitive $\mathrm{Ca}^{2+}$ channels. As we have previously demonstrated, when cells are depolarized by raising $\left[\mathrm{K}^{+}\right]_{0}, \mathrm{Ca}^{2+}$ enters through voltage-sensitive $\mathrm{Ca}^{2+}$ channels (Thayer et al., 1986). This can be blocked by $3 \times 10^{-5} \mathrm{M} \mathrm{La}^{3+}$ (Fig. 6). (It should be noted that divalent channel blockers such as $\mathrm{Cd}^{2+}$ produce spurious effects on the fura- 2 fluorescence and so cannot be used.) $\mathrm{La}^{3+}$, had no effect on the increasc in $\left[\mathrm{Ca}^{2+}\right]_{\mathrm{i}}$ produced by NMDA. Thus, voltage-sensitive $\mathrm{Ca}^{2+}$ channels do not seem to participate in this response. $\mathrm{Li}^{+}$has been reported not to participate in $\mathrm{Na}^{+} / \mathrm{Ca}^{2+}$ exchange (Baker and DiPolo, 1984). When all $\mathrm{Na}^{+}$o was replaced by $\mathrm{Li}^{+}$, there was no rise in $\left[\mathrm{Ca}^{2+}\right]_{i}$, suggesting that normal resting $\left[\mathrm{Ca}^{2+}\right]_{\mathrm{i}}$ does not rely on the activity of this exchange system. Removing $\mathrm{Na}^{+}$o had no effect on NMDA- or depolarization-induced rises in $\left[\mathrm{Ca}^{2+}\right]_{i}$. Replacement of external $\mathrm{Na}^{+}$with the organic cation $\mathrm{N}$-methylD-glucamine (NMDG) also did not have an inhibitory effect on the action of NMDA (Fig. 6).

The most parsimonious explanation of the data is that NMDA activates an ionophore that allows the entry of $\mathrm{Ca}^{2+}$ into the
B

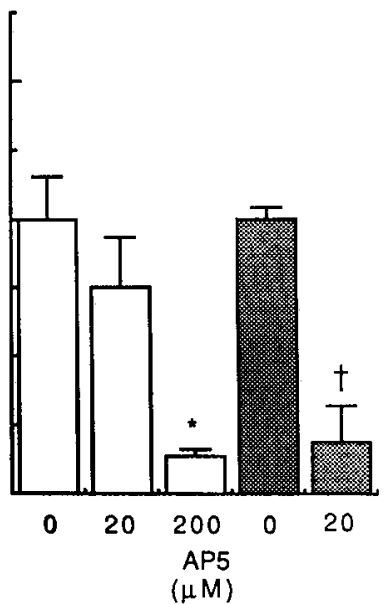

Figure 3. Noncompetitive and competitive antagonisms are shown for the NMDA receptor-linked ionophore in $A$ and $B$, respectively. MK801 and the isomers of dioxadrol are presumptive noncompetitive antagonists. NMDA was applied at either $10 \mu_{\mathrm{M}}$ (filled bars) or $100 \mu \mathrm{M}$ (open bars) in $\mathrm{Mg}^{2+}$-free media. The dagger $(\dagger)$ and asterisk $\left(^{*}\right)$ designate significantly different from control with $p<0.05$ and $p<0.01$, respectively; $n>3$ for all values. $P C P$, phencyclidine; $D E X$, dexoxadrol; $L E V$, levoxadrol. cell. This ionophore is blocked in a voltage-dependent fashion by $\mathrm{Mg}^{2+}$ and $\mathrm{MK} 801$. Voltage-sensitive $\mathrm{Ca}^{2+}$ channels and $\mathrm{Na}^{+} / \mathrm{Ca}^{2+}$ exchange do not seem to participate in this case.

\section{The action of glutamate}

Glutamate is also an agonist at the NMDA receptor. When glutamate was added to striatal ncurons in the absencc of $\mathrm{Mg}^{3+}$, it produced effects that closely resembled those produced by NMDA (Fig. 7). Glutamate was more potent, however, producing significant effects at concentrations of $10^{-6} \mathrm{M}$.

A clear distinction between the actions of NMDA and glutamate was seen however with respect to the effects of $\mathrm{Mg}^{2+}$. In normal physiological medium, which contains sufficient $\mathrm{Mg}^{2+}$ to completely block the effects of NMDA, the effects of glutamate were still manifest. Glutamate was slightly less potent in the presence of $\mathrm{Mg}^{2+}$ than in its absence, and its dose-response curve rose more steeply. However, it was still equally efficacious. The time course of the effects of glutamate observed in the presence of $\mathrm{Mg}^{2+}$ was usually similar to that observed in $\mathrm{Mg}^{2+}$ -
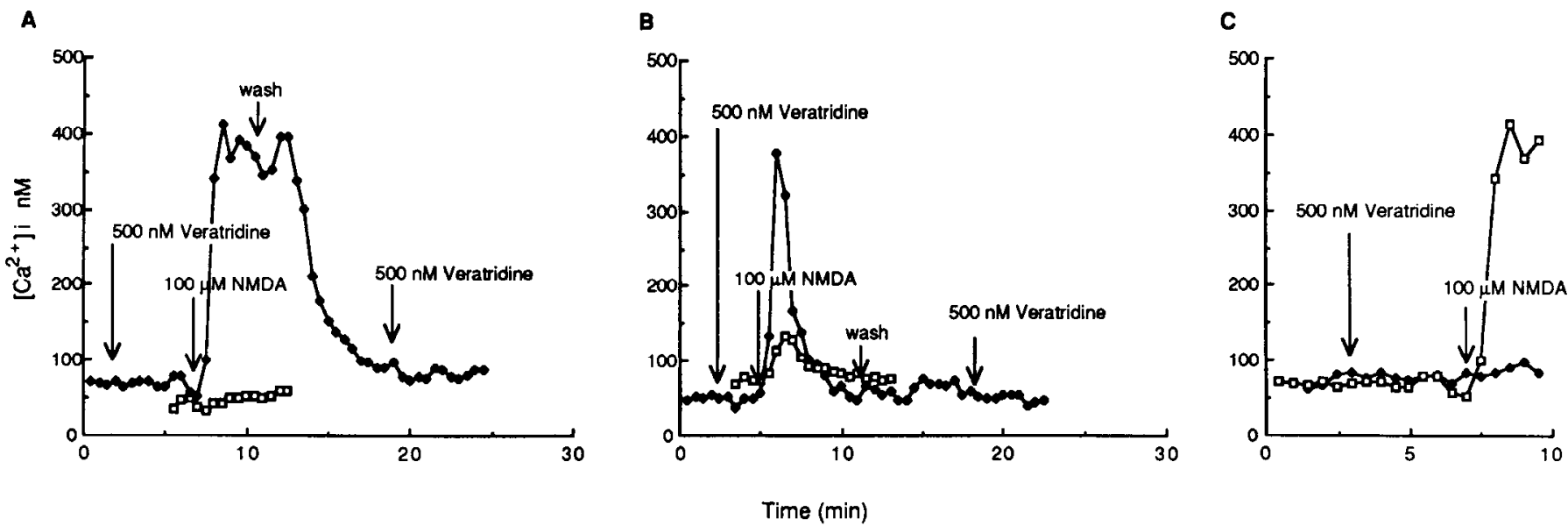

Figure 4. Effects of veratridine depolarization on antagonism of the NMDA response. $A$, In the presence of $0.9 \mathrm{~mm} \mathrm{Mg}^{2+}, \mathrm{NMDA}$ failed to elicit an incrcasc in $\left[\mathrm{Ca}^{2+}\right]_{\mathrm{i}}$ (open squares). Howcver, trcatment with a dose of veratridine that did not activate voltage-sensitive calcium channels (VSCC's) relieved the voltage-dependent block of $\mathrm{Mg}^{2+}$ (solid diamonds). A similar paradigm was used to test the drugs MK801 and AP5 for voltage-sensitive effects. As shown in $B, 1 \mu \mathrm{M}$ MK801 is a potent inhibitor of the NMDA response in $\mathbf{M g}^{2+}$-free media (open squares), and this can be reversed by veratridine (solid diamonds). C, In contrast, the inhibition produced by $1 \mathrm{mM} A P 5$ in $\mathrm{Mg}^{2+}$-free media is not reversed by veratridine (solid diamonds). A control response (with veratridine) is represented by the open squares. 


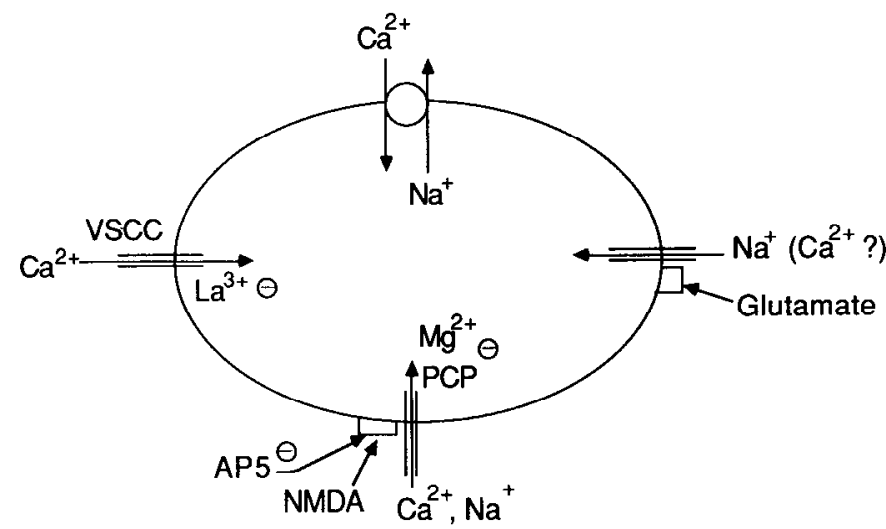

Figure 5. Possible routes of calcium entry into the cell induced by excitatory amino acids.

free medium, although occasionally onset of a response was somewhat delayed. The effects of glutamate in $\mathrm{Mg}^{2}$ । were only slightly blocked by MK801 at concentrations that completely blocked the effects of NMDA (Fig. 8). However, although $\mathbf{M g}^{2+}$ and MK801 were not very effective in blocking the actions of moderate concentrations glutamate, AP5 was a very effective blocker (Figs. 7 and 8). Indeed, the actions of glutamate could be almost completely inhibited by AP5 in a reversible manner. Interestingly, when very high concentrations of glutamate were used $\left(10^{-4} \mathrm{M}\right)$, its effects became resistant to the actions of AP5 (Fig. 8). We also attempted to inhibit the effects of glutamate with other putative blockers of receptors for excitatory amino acids (Fig. 8). Unfortunately, at the concentrations at which these substances are usually employed, we found that most of them produced substantial increases in $\left[\mathrm{Ca}^{2+}\right]_{i}$ by themselves (see also Kudo and Ogura, 1986). At the highest concentrations at which these increases were not seen, only y-D-glutamyl-aminomethylsulphonate (GAMS) produced any inhibition of the glutamate effect. In contrast to NMDA, the effects of $10 \mu \mathrm{M}$ glutamate exhibited little desensitization. This was the case whether glutamate was used in the presence or absence of $\mathrm{Mg}^{2+}$.

We attempted to elucidate the mechanism by which glutamate $\left(3 \times 10^{-5} \mathrm{M}\right)$ increased $\left[\mathrm{Ca}^{2+}\right]_{\mathrm{i}}$ when it was added in the presence of $\mathrm{Mg}^{2+}$. We considered the possibilities previously explored in the case of NMDA. In addition, however, we must also consider the possibility that glutamate can act upon other non-NMDA glutamate receptors and that these may play a role in the production of the response. As with NMDA, the effects of glutamate were virtually completely blocked when all $\left[\mathrm{Ca}^{2+}\right]_{0}$ was removed, indicating that the response was dependent on the influx of $\mathrm{Ca}^{2+}$ (Figs. 7 and 9). The effects of glutamate were not blocked by $3 \times 10^{-5} \mathrm{La}^{3+}$ or altered by replacement of all $\left[\mathrm{Na}^{+}\right]_{0}$ by $\mathrm{Li}^{+}$ (Fig. 9). Furthermore, the effects of glutamate were not blocked by TTX $\left(10^{-6} \mathrm{M}\right)$. However, a clear difference between the effects of glutamate and those of NMDA were noted with respect to the effects of replacement of $\left[\mathrm{Na}^{+}\right]_{0}$ with NMDG. Such replacement had relatively minor effects on the action of NMDA (vide supra); however, the effects of glutamate were substantially inhibited.

These data suggest that the mechanism by which glutamate produces increases in $\left[\mathrm{Ca}^{2+}\right]_{\mathrm{i}}$ differs somewhat from that discussed above for NMDA. The response seems to require $\mathrm{Ca}^{2+}$ influx and does not seem to involve voltage-sensitive $\mathrm{Ca}^{2+}$ channels or $\mathrm{Na}^{+} / \mathrm{Ca}^{2+}$ exchange. Moreover, the effects of glutamate $\left(10^{-5} \mathbf{M}\right)$ are blocked by AP5 and therefore presumably involve the NMDA receptor/ionophore system. However, other observations such as the lack of effect of $\mathrm{Mg}^{2+}$ and MK801 and the increased inhibition on substitution of $\left[\mathrm{Na}^{+}\right]_{u}$ by NMDG indicate that other factors are also involved. We shall discuss a possible mechanism below.

\section{Action of $K A$ and $Q A$}

$\mathrm{KA}$ was also able to provoke large increases in $\left[\mathrm{Ca}^{2+}\right]_{\mathrm{i}}$ (Fig. 10). As in the case of glutamate, the actions of KA were not altered by the presence of $\mathrm{Mg}^{2+}$. Relatively high concentrations of KA $\left(\geq 3 \times 10^{-5} \mathbf{M}\right)$ were required to produce responses both in the presence and absence of $\mathrm{Mg}^{2+}$. The actions of $\mathrm{KA}$ were not inhibited by MK801 but were partially blocked by AP5 (Figs. 10 and 11). However the effects of KA appeared more resistant to the blocking actions of AP5 than those of glutamate or NMDA. Nevertheless, at high concentrations of AP5 the effects of KA were reduced. The responses to $\mathrm{KA}$ also showed a tendency to densensitize, as observed for NMDA (Fig. 10). The effects of $\mathrm{KA}$ were abolished on removal of $\mathrm{Ca}^{2+}$ and were not blocked by $3 \times 10^{-5} \mathrm{M} \mathrm{La}^{3+}$ or affected when $\mathrm{Na}^{+}$was replaced by $\mathrm{Li}^{+}$ (Fig. 12). As with responses to glutamate, however, the effects of KA were substantially reduced when $\left[\mathrm{Na}^{+}\right]_{0}$ was replaced by NMDG.

We also performed a limited number of studies using the glutamate analog QA (Fig. 13). The effects of QA resembled
Figure 6. Effects of ion substitution on calcium influx stimulated by $50 \mathrm{~mm}$ $\mathrm{K}^{+}$or $100 \mu \mathrm{M}$ NMDA (in $\mathrm{Mg}^{2+}$-free media). Control responses (solid bars) were compared to responses obtained in media in which $20 \mu \mathrm{M}$ EGTA was substituted for calcium (labeled in figure), $30 \mu \mathrm{M} \mathrm{La}{ }^{3+}$ was added (stippled bars), $\mathrm{Na}^{+}$was replaced with $137 \mathrm{~mm}$ choline (wide hatched bars), $\mathrm{Na}^{+}$was replaced with $137 \mathrm{mM} \mathrm{Li}^{+}$(hatched bars), and $\mathrm{Na}^{+}$was replaced by $137 \mathrm{mM}$ NMDG (open bars). Dagger $(\dagger)$ and asterisk $\left(^{*}\right)$ designate significantly different from control with $p<0.05$ and $p<$ 0.01 , respectively; $n>4$ for all values.

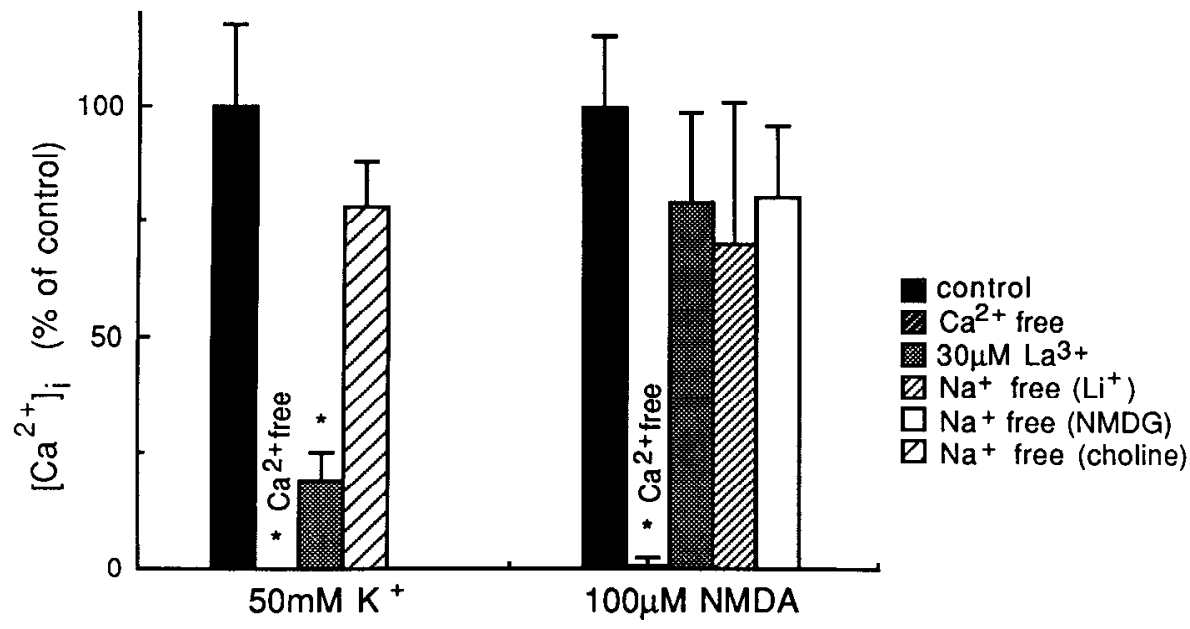


A

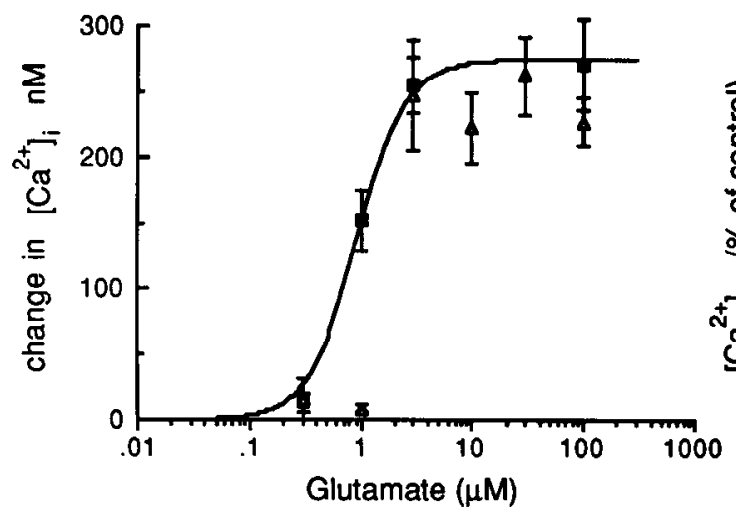

C

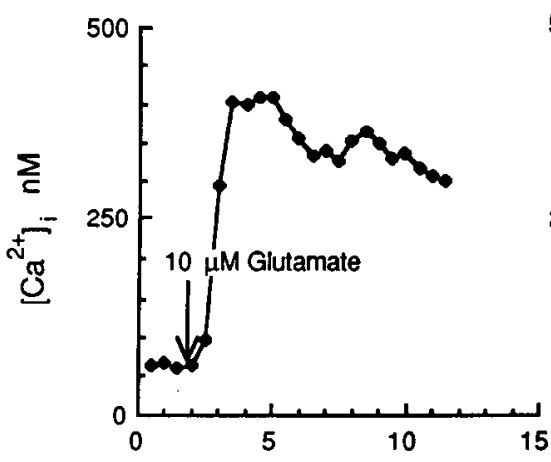

D

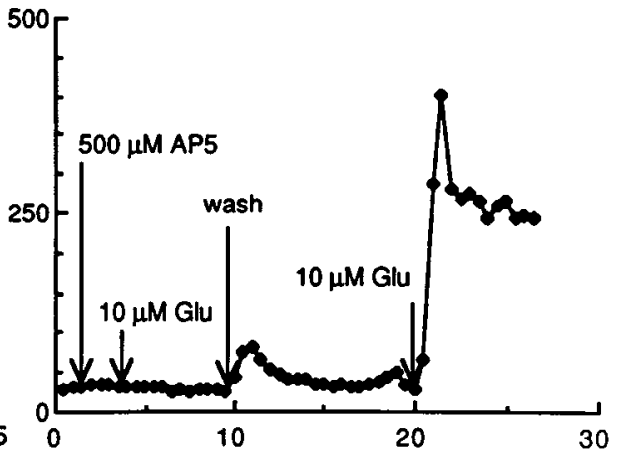

E

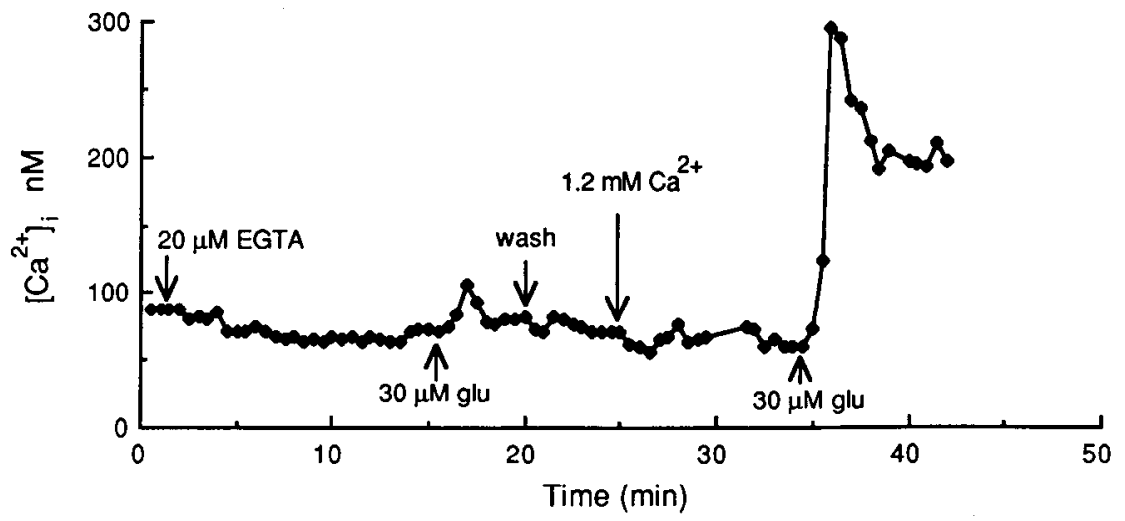

B

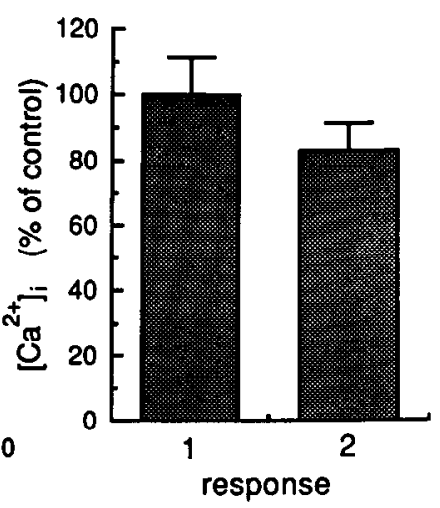
30

Time (min)
Figure 7. Glutamate-induced increases in $\left[\mathrm{Ca}^{2+}\right]_{i}$. Glutamate stimulated a rise in $\left[\mathrm{Ca}^{2+}\right]_{i}$ in a dose-dependent manner in both the presence (open triangles) and absence (solid squares) of $0.9 \mathrm{mM} \mathrm{Mg}^{2+}$. The curve was fit as described in Materials and Methods with the parameters $K_{1}=136.6, K_{2}=$ $0.00053, K_{3}=219.0$ through the $\mathrm{Mg}^{2+}$ free points ( $4<n<19$ for all points). $B$, Attempts to generate a second response using double applications of 10 $\mu \mathrm{M}$ glutamatc as described in Materials and Methods resulted in only a slight attenuation of the response $(n=8)$. $C$, Typical response. $D$, The reversible nature of the block by AP5. E, The trace illustrates the requirement of the glutamate response for external calcium. those of glutamate and KA. Relatively high concentrations of $\mathrm{QA}$ were required to elicit these responses $\left(\geq 10^{-4} \mathrm{M}\right)$. QA was effective in the presence of $\mathrm{Mg}^{2+}$ and $\mathrm{MK} 801$. As in the case of glutamate and $\mathrm{KA}$, the responses to QA could be blocked by AP5. However, as with KA, high concentrations of AP5 were required, and only a partial block was achieved even at these concentrations. The QA analog $\alpha$-amino-3-hydroxy-5-methyl4-isoxazolepropionic acid (AMPA) produced effects that resembled those of QA.

\section{Discussion}

The major finding in the present study is that glutamate and various types of glutamate agonists substantially increase $\left[\mathrm{Ca}^{2+}\right]_{i}$ in striatal neurons. This is true for agonists that activate NMDA and non-NMDA receptors alike. These findings are consistent with the proposal that excitotoxicity is associated with an increase in $\left[\mathrm{Ca}^{2+}\right]_{\mathrm{i}}$ (Choi, 1985, 1987; Garthwaite and Garthwaite, 1986; Garthwaite et al., 1986; Hajos et al., 1986). Clearly, however, the notion that an increase in $\left[\mathrm{Ca}^{2+}\right]_{i}$ is actually responsible for excitotoxicity is neither supported or negated by our observations. We shall now discuss a model to explain these various observations. For convenience we adopt the nomenclature suggested by O'Brien and Fischbach (1986), who designated the NMDA-type glutamate receptor as $\mathrm{G}_{1}$ and the non-NMDA glutamate receptor as $G_{2}$. Clearly, however, we realize that this may ultimately prove to be an oversimplification and that there may either be more than one type of $G_{2}$ receptor or that all types of excitatory amino acid receptors may actually be separate functional manifestations of a single type of ionophore complex gated in diverse ways (Cull-Candy and Usowicz, 1987; Jahr and Stevens, 1987). 
A

Figure 8. Antagonism of glutamatestimulated increases in $\left[\mathrm{Ca}^{2+}\right]_{i} . A$, Antagonists for the glutamate receptor. Glutamate was used at $10 \mu \mathrm{M}$. $B$, The maximum inhibition of various glutamate concentrations-3 $\mu \mathrm{M}$ (hatched bar), $10 \mu \mathrm{M}$ (filled bar), or $100 \mu \mathrm{M}$ (open bar)-obtained with increasing doses of AP5. Dagger $(\dagger)$ and asterisk $\left(^{*}\right)$ designate significantly different from control with $p<0.05$ and $p<0.01$, respectively; $n>3$ for all values.

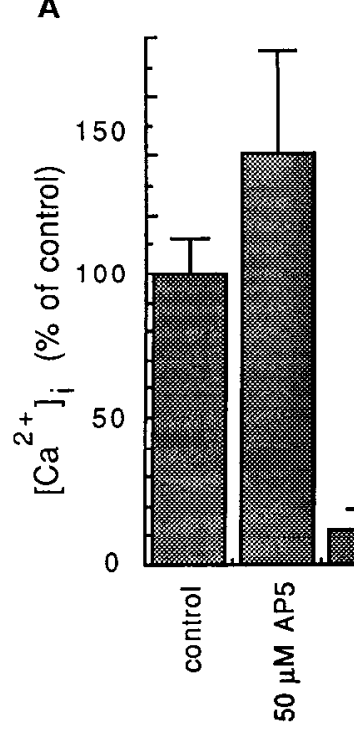

B

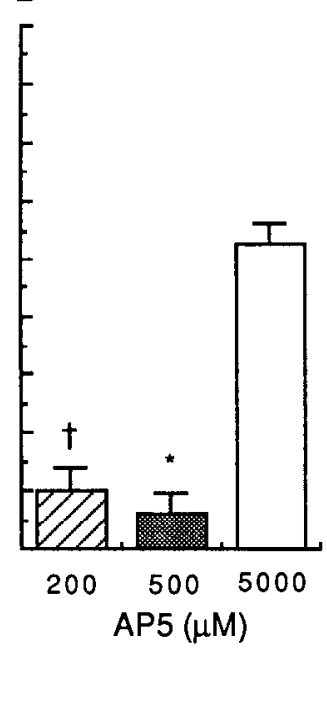

\section{Effects of NMDA}

NMDA clearly produced rapid increases in $\left[\mathrm{Ca}^{2+}\right]_{i}$ in striatal neurons. Such results are consistent with some very recently reported measurements using fura-2 microspectrofluorimetry and single hippocampal neurons (Kudo and Ogura, 1986), in which NMDA was also effective in raising $\left[\mathrm{Ca}^{2+}\right]_{i}$. Our results are also quite consistent with several previous studies on the properties of the $G_{1}$ receptor/ionophore complex. The ionophore activated by $G_{1}$ agonists has a conductance of about 50 pS (Nowak et al., 1984; Cull-Candy and Ogden, 1985; O'Brien and Fischbach, 1986; Cull-Candy and Usowicz, 1987; Jahr and Stevens, 1987) and appears to be permeable to a variety of cations, including $\mathrm{Ca}^{2+}$ (Ascher and Nowak, 1986; MacDermott et al., 1986; Mayer and Westbrook, 1987a; Jahr and Stevens, 1987; Mayer et al., 1987). Of particular interest is the wellestablished observation that this ionophore can be blocked in a voltage-dependent fashion by $\mathrm{Mg}^{2+}$ (Mayer et al., 1984; Nowak et al., 1984; Mayer and Westbrook, 1987b) and other divalent cations (e.g., $\mathrm{Ni}^{2+}, \mathrm{Co}^{2+}$, and $\mathrm{Mn}^{2+}$ ) at submillimolar concentrations (Nowak and Ascher, 1985; Mayer and West- brook, 1986, 1987b). Interestingly, low concentrations of $\mathrm{Cd}^{2+}$ are rather ineffective blockers (Mayer et al., 1984; Mayer and Westbrook, 1987a), an observation that clearly distinguishes this ionophore from the various types of voltage-sensitive $\mathrm{Ca}^{2+}$ channels that are potently blocked by $\mathrm{Cd}^{2+}$ (Hagiwara and Byerly, 1981). High concentrations of $\mathrm{Ca}^{2+}$ and $\mathrm{Ba}^{2+}\left(>5 \times 10^{-3}\right.$ M) can also act as NMDA antagonists, decreasing single-channel conductance (Nowak and Ascher, 1985). The fact that the $\mathrm{G}_{1}$ linked ionophore exhibits an appreciable permeability to $\mathrm{Ca}^{2+}$ suggests that it may be the primary route for $\mathrm{Ca}^{2+}$ entry seen in our studies. Indeed, all our observations support this proposal. The effect of NMDA is clcarly blocked by $\mathrm{Mg}^{2+}$ in a voltage-dependent fashion. It should be noted that the $\mathrm{Mg}^{2+}$ dependent block can be relieved by very low concentrations of veratridine, which depolarizes cells by allowing sustained $\mathrm{Na}^{+}$ entry via voltage-sensitive $\mathrm{Na}^{+}$channels. The concentration of veratridine employed clearly does not depolarize the neurons sufficiently to allow $\mathrm{Ca}^{2+}$ entry via voltage-sensitive $\mathrm{Ca}^{2+}$ channels. This is consistent with previous electrophysiological studies. Thus if our striatal neurons have a resting potential of about $-70 \mathrm{mV}$, a depolarization of $20-30 \mathrm{mV}$ would be sufficient to
Figure 9. Effects of ion substitution on calcium influx stimulated by $30 \mu \mathrm{M}$ glutamate in $\mathbf{M g}^{2+}$-containing media. The control response (solid bar) is compared to responses in which $20 \mu \mathrm{M}$ EGTA was substituted for calcium (filled hatched bars), $30 \mu \mathrm{M} \mathrm{La}{ }^{3+}$ was added (stippled bars), $\mathrm{Na}^{+}$was replaced with $137 \mathrm{mM} \mathrm{Li}^{+}$(hatched bars), $\mathrm{Na}^{+}$was replaced by 137 mM NMDG (open bars), and $1 \mu \mathrm{M}$ TTX was added (wide hatched bars). Dagger $(\dagger)$ and asterisk $\left(^{*}\right)$ designate significantly different from control with $p<0.05$ and $p<0.01$, rcspectively; $n>4$ for all values.

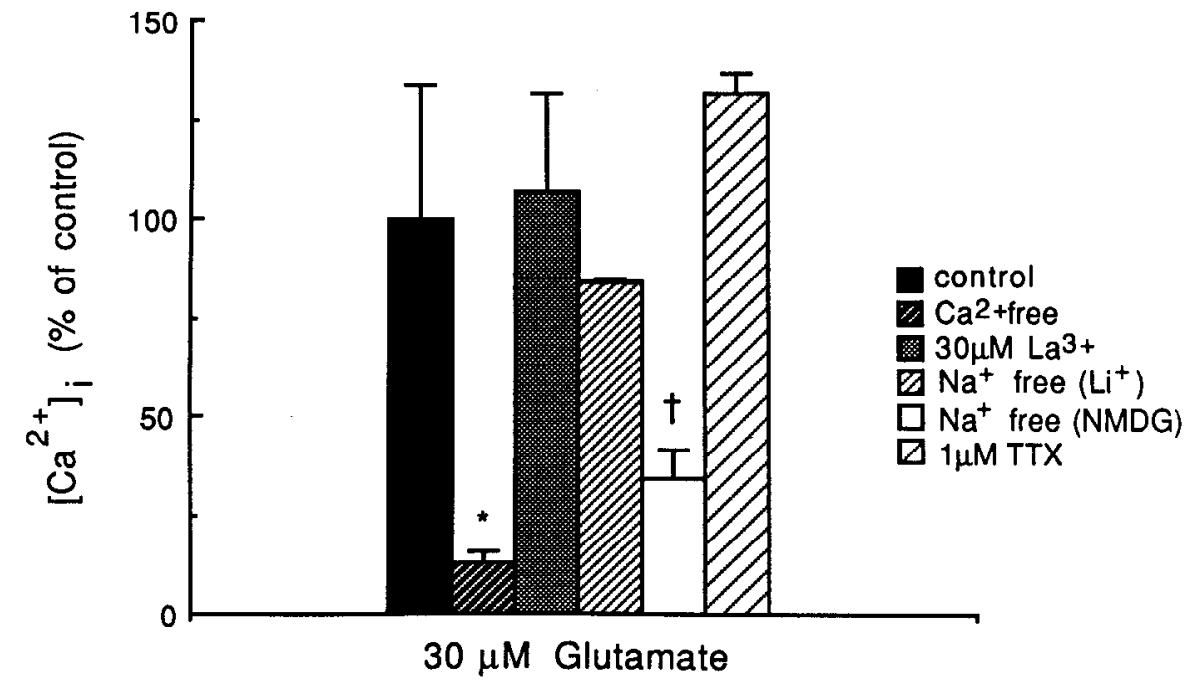


A

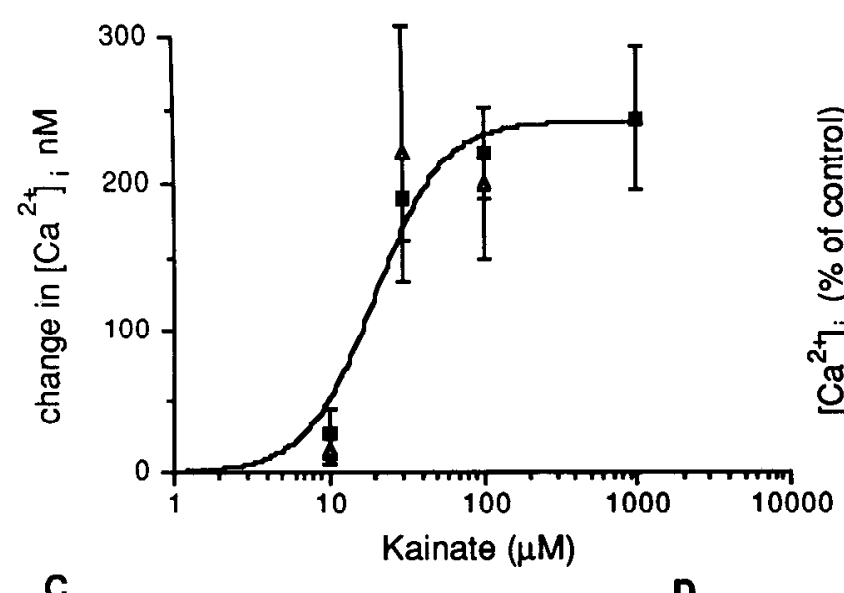

B

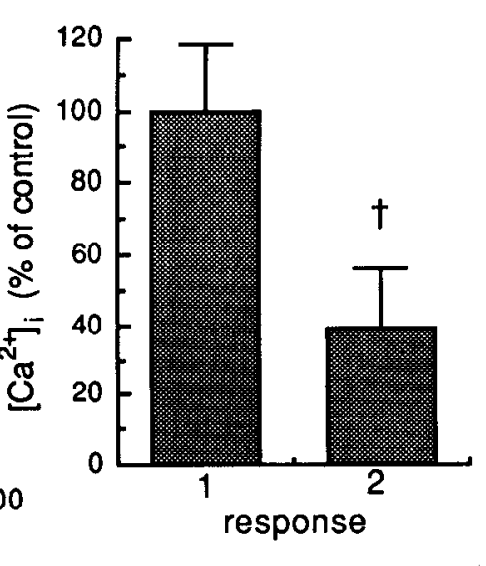

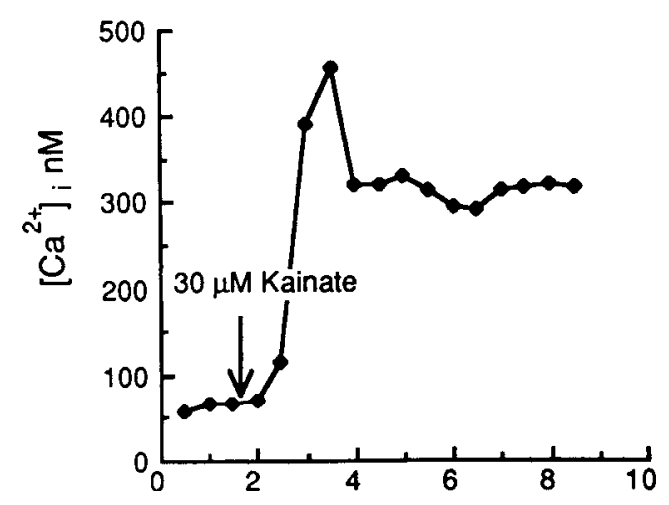

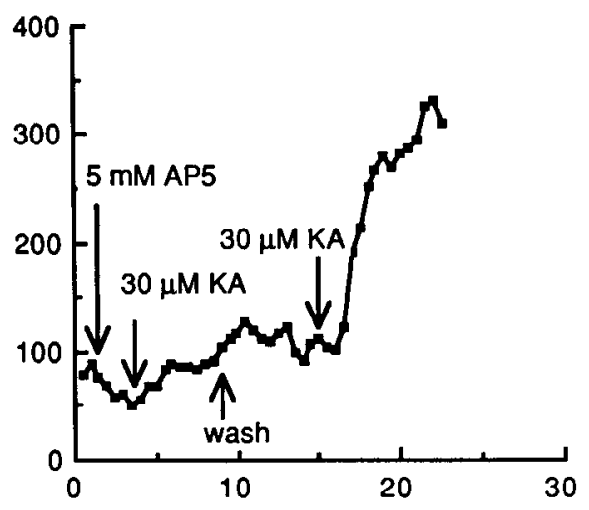

Figure 10. A, Kainic acid-induced increases in $\left[\mathrm{Ca}^{2+}\right]_{\mathrm{i}}$. Increasing concentrations of kainate stimulated a rise in $\left[\mathrm{Ca}^{2+}\right]_{\mathrm{i}}$ in both the presence (open triangles) and absence (solid squares) of $0.9 \mathrm{~mm} \mathrm{Mg} \mathrm{Mg}^{2+}$. The curve was fit as described in Materials and Methods with the parameters $K_{1}=121.5, K_{2}=8.9 \times$ $10^{-5}, K_{3}=29.2$ using the values obtained in $\mathrm{Mg}^{2+}$-containing media $4<$ $n<19$ for all points). $B$, Attempts to generate a second response, as described in Materials and Methods, resulted in a $61 \%$ attenuated response $(p<$ $0.05, n=5$ ). $C$. Typical response. $D$, Reversible nature of the block by $5 \mathrm{~mm}$ AP5. relieve the block of the $\mathrm{G}_{1}$ ionophore by $\mathrm{Mg}^{2+}$ but not to activate voltage-sensitive $\mathrm{Ca}^{2+}$ channels that require stronger depolarizations (Nowycky et al., 1985). Block of the NMDA response by PCP/MK801-like agents also seems to be voltage dependent, supporting previous suggestions that the locus of action of these compounds is at the level of the ionophore rather than the NMDA recognition site (Honey et al., 1985). 'The effect of NMDA seems to depend on the influx of $\mathrm{Ca}^{2+}$, as completely removing all $\left[\mathrm{Ca}^{2+}\right]_{0}$ eliminates the response. Such data is consistent with other studies that show that NMDA increases the uptake of ${ }^{45} \mathrm{Ca}^{2+}$ by brain cells in primary culture or in slice preparations (Ichida et al., 1982; Retz et al., 1982; Retz and Coyle, 1984; Harris, 1985; Wroblewski et al., 1985, 1987; Riveros and Orrego, 1986). It is conceivable that this initial entry of $\mathrm{Ca}^{2+}$ is now amplified if it triggers a secondary release of $\mathrm{Ca}^{2+}$ from intracellular bound stores. However, although such mechanisms may occur in some peripheral neurons (MacDermott and Weight, 1982; Smith et al., 1983; Neering and McBurney, 1984), we found little evidence for such effects in our studies. Furthermore, abolition of the effects of NMDA on removal of $\left[\mathrm{Ca}^{2+}\right]_{\circ}$ also suggests that NMDA does not function through its reported degradation of phosphatidyl inositol bisphosphate and generation of inositol trisphosphate (Nicoletti et al., 1986a, b, 1987; Sugiyama et al., 1987). As the $G_{1}$ ionophore is also permeable to $\mathrm{Na}^{+}$(Nowak et al., 1984; Mayer and Westbrook 1987a; Jahr and Stevens, 1987), we also examined the potential role of $\mathrm{Na}^{+}$ in the NMDA response. Cell depolarization due to the entry of $\mathrm{Na}^{+}$(and also $\mathrm{Ca}^{2+}$ ) could lead to the opening of voltage-sen-

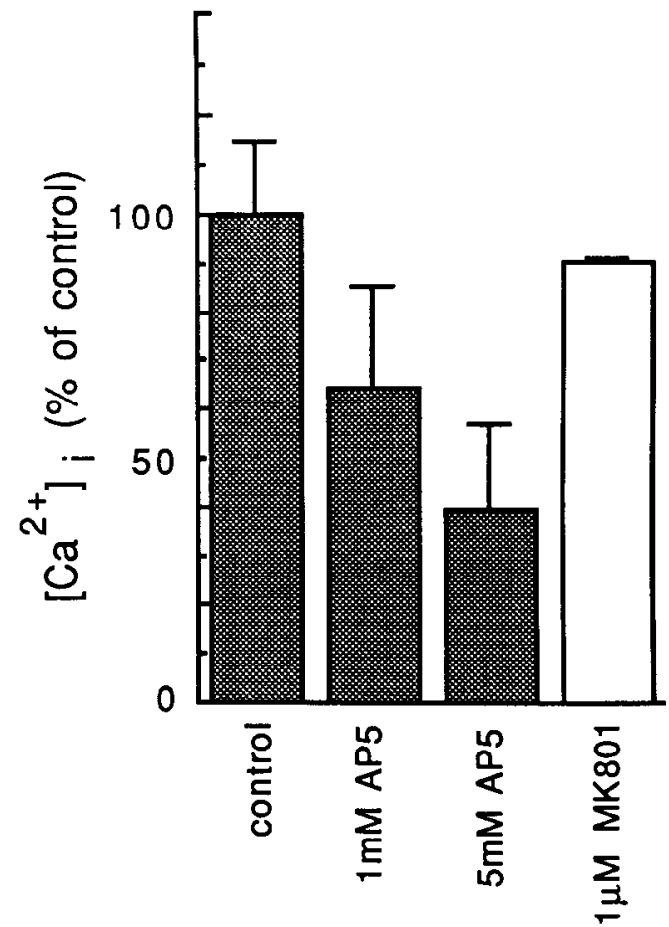

Figure 11. Inhibition of the kainate response by AP5 and MK801. Antagonists were tested against $30 \mu \mathrm{M}$ (solid bars) or $100 \mu \mathrm{M}$ kainic acid (open bars); $n>3$ for all values. 
Figure 12. Effects of ion substitution on calcium influx stimulated by $100 \mu \mathrm{M}$ kainate. The control response (solid bar) was compared to responses obtained in media in which $20 \mu \mathrm{M}$ EGTA was substituted for calcium (filled hatched bars) $30 \mu \mathrm{M} \mathrm{La}^{3+}$ was added (stippled bars), $\mathrm{Na}^{+}$was replaced with $137 \mathrm{mM} \mathrm{Li}{ }^{+}$ (hatched bars), and $\mathrm{Na}^{+}$was replaced by 137 mM NMDG (open bars). Dagger $(\dagger)$ and asterisk $\left(^{*}\right)$ designate significantly different from control with $p<$ 0.05 and $p<0.01$, respectively; $n>4$ for all values.

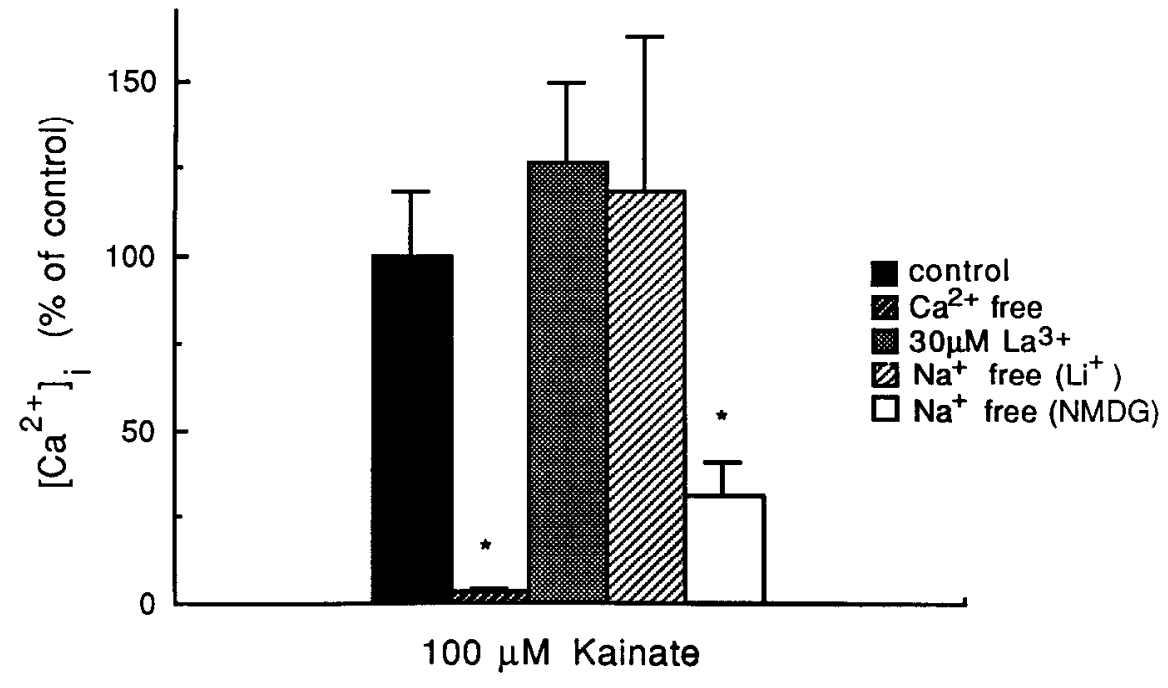

sitive $\mathrm{Ca}^{2+}$ channels and the subsequent entry of $\mathrm{Ca}^{2+}$. However, in the presence of a concentration of $\mathrm{La}^{3+}$ that blocked voltagedependent $\mathrm{Ca}^{2+}$ entry, NMDA-stimulated $\mathrm{Ca}^{2+}$ uptake was fully maintained. Furthermore, NMDA-linked $\mathrm{Na}^{+}$entry could reverse $\mathrm{Na}^{+} / \mathrm{Ca}^{2+}$ exchange or at least decrease $\mathrm{Ca}^{2+}$ extrusion, leading to an increase in $\left[\mathrm{Ca}^{2+}\right]_{\mathrm{i}}$. Complete substitution of all $\mathrm{Na}^{+}{ }_{\circ}$ by $\mathrm{Li}^{+}$, however, failed to reduce the response to NMDA or increase basal $\left[\mathrm{Ca}^{2+}\right]_{i}$. In squid axon, at any rate, $\mathrm{Li}^{+}$cannot utilize the $\mathrm{Na}^{+} / \mathrm{Ca}^{2+}$ system (Baker and DiPolo, 1984). Substitution of $\mathrm{Na}^{+}{ }_{0}$ by $\mathrm{NMDG}$ also failed to reduce the response to NMDA. This supports the interpretation that depolarization of the membrane by sodium is not involved in the actions of NMDA in $\mathrm{Mg}^{2+}$-free media, since large organic cations are not believed to pass through the $G_{1}$ ionophore (Nowak and Ascher, 1984). Overall, the most parsimonious interpretation of our data is that NMDA activates an ionophore that is $\mathrm{Ca}^{2+}$ permeable and blocked in a voltage-dependent manner by $\mathrm{Mg}^{2+}$ and that this is the route of NMDA-activated $\mathrm{Ca}^{2+}$ uptake.

\section{Effects of glutamate}

Glutamate acts as an agonist at $\mathrm{G}_{1}$ receptors (Mayer and Westbrook, 1984, 1987a; Westbrook and Mayer, 1984; O'Brien and Fischbach, 1986). Thus, in the absence of $\mathrm{Mg}^{2+}$ the glutamateinduced increase in $\left[\mathrm{Ca}^{2+}\right]_{i}$ presumably reflects activation of the same mechanisms discussed above for NMDA. However, there are several important differences in the responses to NMDA and glutamate. The most striking of these is that $\mathrm{Mg}^{2+}$ does not block the effects of glutamate. An obvious interpretation of such an observation is that glutamate can activate another type of ionophore $\left(\mathrm{G}_{2}\right.$ ?) in addition to the $\mathrm{G}_{1}$ receptor and that this second ionophore is also $\mathrm{Ca}^{2+}$ permeable. However, some properties of the ionophore(s) activated by $G_{2}$ agonists have been reported. It has a smaller conductance than the $G_{1}$-linked ionophore (O'Brien and Fischbach, 1986; Cull-Candy and Usowicz, 1987; Jahr and Stevens, 1987). Although it appears to be permeable to monovalent cations, it has been reported not to be appreciably permeable to $\mathrm{Ca}^{2+}$ (MacDermott et al., 1986; Mayer et al., 1987). Thus, increasing $\left[\mathrm{Ca}^{2+}\right]_{\text {o }}$ causes a depolarizing shift in the reversal potential for NMDA-activated currents in CNS neurons but only a slight shift for KA-induced currents (MacDermott et al., 1986; Mayer and Westbrook, 1987b). Let us start by considering a separate mechanism. It may be supposed that $G_{1}$ and $G_{2}$ receptors coexist on the vast majority of glutamate-sensitive striatal neurons. We have not systematically investigated this question, as we wished to avoid the complicating effects of desensitization. However, other studies have clearly supported this contention (Nowak et al., 1984; Mayer and Westbrook, 1987a; Jahr and Stevens, 1987). Glutamate acts
Figure 13. A, Dose-response curve for the effects of quisqualate in $\mathbf{M g}^{2+}$-containing media ( $3<n<7$ for all values). The curve was fit as described in Materials and Methods with the parameters $K_{1}=86.6, K_{2}=3.5 \times 10^{-7}, K_{3}=$ 1089. $B$, Typical response to the agonist AMPA.
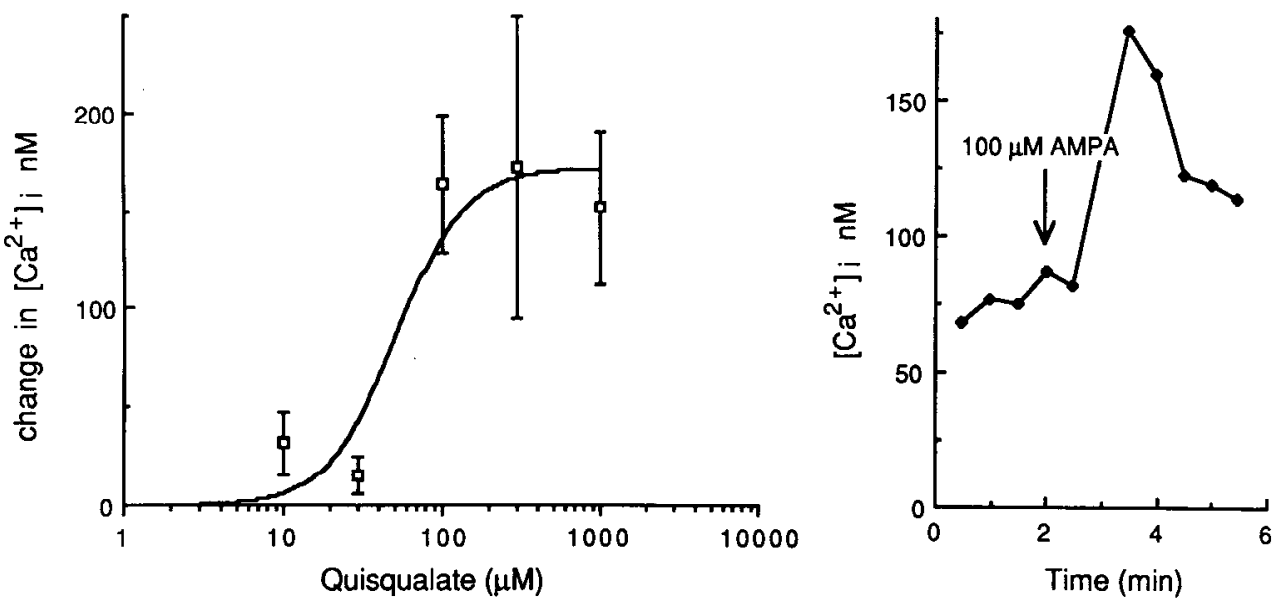
as an agonist at both these receptor types. The effects of adding glutamate will therefore be functionally very similar to those of adding NMDA and veratridine simultaneously in the presence of $\mathrm{Mg}^{2+}$. Glutamate acting at the $\mathrm{G}_{2}$ site will activate a $\mathrm{Na}^{+}$ ionophore (the $\mathrm{G}_{2}$ ionophore) and produce depolarization, i.e., the same ultimate result as activation of the voltage-sensitive $\mathrm{Na}^{+}$channel by veratridine. The degree of depolarization produced by moderate concentrations of glutamate might, in fact, be expected to be in the range of $20-30 \mathrm{mV}$ (e.g., Rothman, 1985; Rothman and Samaie, 1985). This would be enough to reduce the voltage-dependent block of $\mathrm{G}_{1}$ by $\mathrm{Mg}^{2+}$ but not enough to activate voltage-dependent $\mathrm{Ca}^{2+}$ channels. Indeed, the effects of glutamate are not blocked by $\mathrm{La}^{3+}$. As glutamatc can also activate $G_{1}$ receptors, it will simultaneously be able to evoke $\mathrm{Ca}^{2+}$ uptake via the $\mathrm{G}_{1}$-linked ionophore. In effect the action of glutamate at $G_{2}$ exerts a permissive effect for the simultaneous action of glutamate at $G_{1}$. Several of our observations are consistent with this model. The most striking is that even in the presence of $\mathrm{Mg}^{2+}$ the effects of moderate concentrations of glutamate are completely blocked by AP5, suggesting the involvement of the $G_{1}$ complex. Second, it can be seen that substitution of $\mathrm{Na}^{+}{ }_{0}$ by $\mathrm{Li}^{+}$does not reduce the effects of glutamate, whereas substitution by NMDG has quite a strong suppressive effect. It may well be that $\mathrm{Li}^{+}$can permeate the $\mathrm{G}_{2}$-linked ionophore and thus participate in $\mathrm{G}_{2}$-linked depolarization as can $\mathrm{Na}^{+}$. However, if NMDG is not permeable, depolarization would not be produced, and the permissive effect of $\mathrm{G}_{2}$ activation would not occur. (It is also possible, however, that NMDG may have a blocking effect at the $\mathrm{G}_{2}$ ionophore, an effect that would also be consistent with our observations.) The effects of glutamate were also not blocked by MK801. This could also be explained by the voltage dependence of the action of this drug at $\mathrm{G}_{1}$ (vide supra). One problematic series of experiments concerns studies on the effects of agents that are supposed to act as $G_{2}$ or $G_{1} / G_{2}$ antagonists. We found that when we used these agents at concentrations at which others have used them, most of them caused increases in $\left[\mathrm{Ca}^{2+}\right]_{i}$ by themselves. At concentrations where this did not occur, most of these agents were ineffective. The exception was GAMS, which did block some of the glutamate effect. Our experience has apparently been shared by Kudo and Ogura (1986), who observed similar "nonspecific" effects of these so-called blockers in hippocampal pyramidal cells. In addition these authors also reported that AP5 produced similar effects. In general, however, we have not found such spurious actions of AP5 up to concentrations of $5 \mathrm{~mm}$. Thus, our observations are all consistent with the participation of the $G_{1}$ complex in the response to glutamate in the presence of $\mathrm{Mg}^{2+}$. Other observations such as the lack of effect of $\mathrm{La}^{3+}$ and the effect of the removal of $\left[\mathrm{Ca}^{2+}\right]_{0}$ are also consistent with this model.

Ihe alternative explanation would be that the $\mathrm{G}_{2}$ ionophore does have a significant permeability to $\mathrm{Ca}^{2+}$. It could be supposed that although the $\mathrm{G}_{2}$ permeability to $\mathrm{Ca}^{2+}$ was much less than that for $G_{1}, G_{2}$ receptors were found in much greater abundance than $G_{1}$ receptors, and thus the net cellular rise in $\left[\mathrm{Ca}^{2+}\right]_{i}$ might be the same. In this case, the blocking effects of AP5 would have to be mediated at the $G_{2}$ site. Again, however, there is no evidence for such a proposal. Indeed, O'Brien and Fischbach (1986) demonstrated that even at $1 \mathrm{mM}$ AP5 had no effect whatsoever on the conductance activated by $\mathrm{G}_{2}$ agonists in chick motoneurons in vitro. Thus, for moderate concentrations of glutamate, the mechanism we have discussed seems the most likely. It should be noted, though, that when very high concentrations of glutamate are used, the response becomes much less sensitive to blockade by AP5, suggesting that alternative mechanisms may also come into play. The lack of effect of AP5 cannot be explained solely on the basis that higher AP5 concentrations would be needed to compete with higher concentrations of glutamate. Recently, Jahr and Stevens (1987) and Cull-Candy and Usowicz (1987) have suggested that $G_{1} / G_{2}$ receptors may, in fact, form a functionally linked complex. They suggest that the different actions of $G_{1}$ and $G_{2}$ agonists merely reflect the stabilization of distinct conductance states in this complex. Large, medium, and small conductance states are found. Of these, the large conductance state clearly corresponds to that previously identified with the $G_{1}$ ionophore. Interestingly, although $G_{2}$ agonists tend to stabilize the smaller $\mathrm{Ca}^{2+}$-impermeable conductance states, they do also produce some openings of the large, $\mathrm{Ca}^{2+}$-permeable conductance state, although much less frequently than $G_{1}$ agonists. Clearly, therefore, according to this model, $\mathrm{G}_{2}$ agonists might be expected to cause some $\mathrm{Ca}^{2+}$ entry directly. According to Jahr and Stevens, lower concentrations of glutamate tend to behave like NMDA and produce mostly large conductance state openings; however, high concentrations of glutamate favor the smaller, relatively $\mathrm{Ca}^{2+}$-impermeable states.

\section{Effects of $K A$ and $Q A$}

In most respects the effects of KA and, in so far as we have pursued them, of QA resemble those of glutamate. This is true with respect to their resistance to the blocking effects of $\mathrm{Mg}^{2+}$ and MK801, the effect of various ionic manipulations, substitutions, etc. We propose that the same 2 mechanisms operate here as with the glutamate receptor. The NMDG/AP5-blockable parts of a response represent activation of the $G_{1}$ receptor. The most significant problem with this mechanism is that it necessitates agonist effects of KA and $Q A$ at $G_{1}$, as well as $G_{2}$. Is such a proposal reasonable? It should be noted that the effects of $\mathrm{KA}$ and QA seen in our studies require relatively high concentrations of these agonists. Is there any evidence for $G_{1}$ effects of $K A$ and QA even at elevated concentrations? Electrophysiological studies are difficult to judge in this respect, although many studies might be interpreted as suggesting a small $G_{1}$ contamination of the basically $\mathrm{G}_{2}$ effects of KA and QA (Mayer and Westbrook, 1987a). In MacDermott et al. (1986; Fig. 3), this could also explain the small rise in $\left[\mathrm{Ca}^{2+}\right]_{i}$ evoked by $10^{-4} \mathrm{M} \mathrm{KA}$. The most accurate data should come from ligand binding studies. Unfortunately, although their pharmacology is relatively sophisticated, $G_{1}$ receptors have been difficult to identify unequivocally in biochemical paradigms. Until recently no consensus had been reached with respect to such studies (Foster and Fagg, 1984). Recently, however, a novel ligand 3-(2-carboxypiperazin-4-yl)propyl-1-phosphonic acid (CPP) has been introduced that appears to have been used successfully by at least 2 groups for labeling $G_{1}$ sites (Olverman et al., 1986; Murphy et al., 1987). Interestingly, Olverman et al. (1986) observed that the $K_{\mathrm{i}}$ values for the inhibition of ${ }^{3} \mathrm{H}$-CPP binding to $\mathrm{G}_{1}$ sites in rat cortical membranes were $10^{-4} \mathrm{M}$ for QA and $2.8 \times$ $10^{-4} \mathrm{M}$ for $\mathrm{KA}$. These are clearly in the same range as the concentrations found to be effective in the present studies. Unfortunately, the $K_{\mathrm{i}}$ for AMPA is about $10^{-4} \mathrm{M}$, and we have shown that lower concentrations of this $\mathrm{QA}$ analug are also effective in raising $\left[\mathrm{Ca}^{2+}\right]_{i}$. Responses resistant to NMDG substitution and high doses of AP5 could represent $\mathrm{Ca}^{2+}$ permeability through the $\mathrm{G}_{2}$ ionophore. In the case of $\mathrm{KA}$ and $\mathrm{QA}$, 
the observations of Jahr and Stevens (1987) and Cull-Candy and Usowicz (1987) are particularly useful, as they help to explain the situation. Thus, presumably the AP5-resistant portion of the effects observed could be due to the activation of the large conductance $\mathrm{Ca}^{2+}$-permeable state of the channel by the $\mathrm{G}_{2}$ rather than the $G_{1}$ receptor. However, one wishes to view the situation, the conclusion must be that under the conditions of our experiments all the amino acids we have used induce $\mathrm{Ca}^{2+}$ uptake predominately via receptor-linked ionophores rather than by $\mathrm{o}$ :her routes.

\section{Relationship to other studies and implications for excitotoxicity}

We have suggested a model that provides a mechanism for the excitatory amino acid-induced increase in $\left[\mathrm{Ca}^{2+}\right]_{i}$ observed in our studies. However, is this indeed the manner in which excitatory amio acids causes increases in $\left[\mathrm{Ca}^{2+}\right]_{\mathrm{i}}$ in vivo or even in other systems in vitro? The most comparable study is that by Kudo and Ogura (1986), who used fura-2 microspectrofluorimetry to analyze the effects of glutamate on $\left[\mathrm{Ca}^{2+}\right]_{i}$ in hippocampal pyramidal cells in vitro. There is excellent agreement between the results of that study and those reported here. This applies to values for the resting $\left[\mathrm{Ca}^{2+}\right]_{i}$ in neurons and to the size of the increment in $\left[\mathrm{Ca}^{2+}\right]_{i}$ produced by glutamate. These authors also found no effect on blocking voltage-sensitive $\mathrm{Ca}^{2+}$ channels or substitution of $\mathrm{Na}^{+}{ }_{0}$. Several other studies have utilized radiotracers to analyze the effects of excitatory amino acids on neuronal $\mathrm{Ca}^{2+}$ uptake (Ichida et al., 1982; Retz et al., 1982; Retz and Coyle, 1984; Harris, 1985; Wroblewski et al., 1985, 1987; Riveros and Orrego, 1986). In most cases, these results are difficult to interpret. An exception is a recent study by Wroblewski et al. (1987) on primary cultures of cerebellar granule cells. These authors observed that NMDA and KA could increase ${ }^{45} \mathrm{Ca}^{2+}$ uptake by these cultures. The effects of KA were somewhat reduced by AP5, as in the present study. Rather than suggesting the mechanism we have proposed, Wroblewski et al. suggest a reasonable alternative. They propose that the KA effect is mediated presynaptically and involves the secondary release of a glutamate-like neurotransmitter, which could then activate $\mathrm{G}_{1}$-linked channels (Ferkany et al., 1982).

Although such an explanation is clearly reasonable, we do not believe that it explains the effects we observed. In several instances we have observed the effects of NMDA, glutamate, KA, and QA on isolated cells that clearly did not form contacts with other neurons. ${ }^{45} \mathrm{Ca}^{2+}$ uptake studies only monitor events in a population of cells and cannot distinguish between the mechanisms proposed by us and by Wroblewski et al. However, the ability to analyze $\left[\mathrm{Ca}^{2+}\right]_{\mathrm{i}}$ in single cells allows us to make this distinction. It is, of course, conceivable that different mechanisms underlie the events observed in cerebellar granule cells and those observed in striatal neurons. In general, it is encouraging to note that results from 3 culture systems using striatal, hippocampal, and cerebellar neurons are extremely compatible. Several studies have also analyzed the effects of excitatory amino acids on $\mathrm{Ca}^{2+}$ movements in situ or in brain slices by monitoring the removal of $\mathrm{Ca}^{2+}$ from the extracellular space using ionsensitive electrodes. Excitatory amino acids of all classes are able to provoke a large apparent uptake of $\mathrm{Ca}^{2+}$ in the cortex, hippocampus, and spinal cord (Heinemann and Pumain, 1980, 1981; Marciani et al., 1982; Buhrle and Sonnhof, 1983; Zanotto and Heinemann, 1983; Heinemann et al., 1984; Korf and Postema, 1984; Pumain and Heinemann, 1985; Ashton et al., 1986;
Hamon and Heinemann, 1986; Sakamoto et al., 1986). The authors of these studies have usually concluded that the uptake is due to the influx of $\mathrm{Ca}^{2+}$ through both ligand-gated and voltage-sensitive ionophores. However, such conclusions are generally based on the blocking effects of divalent cations. As we have discussed, such cations generally block the $G_{1}$-linked ionophore in addition to voltage-sensitive $\mathrm{Ca}^{2+}$ channels, and so such conclusions may be unwarranted. Nevertheless, it is quite conceivable that, under other in vitro, in situ, or certain pathological conditions, excitatory amino acids may depolarize cells sufficiently to allow $\mathrm{Ca}^{2+}$ influx by routes other than the $\mathrm{G}_{1} / \mathrm{G}_{2}$ linked ionophores (e.g., Mayer et al., 1987).

If indeed our hypothesis correctly explains some aspects of excitatory amino acid-induced $\mathrm{Ca}^{2+}$ uptake occurring in situ and if such an increase is actually responsible for excitotoxicity, then certain predictions should be testable. The first is that drugs such as MK801 should protect against NMDA-induced toxicity much more effectively than KA-induced toxicity. This is certainly found to be the case in the striatum and hippocampus (Foster et al., 1986). Furthermore, we would expect AP5 to protect somewhat against $\mathrm{KA}$-induced toxicity. In a recent study of the toxic effects of excitatory amino acids on the retina in vitro, Olney et al. (1986) observed that AP5 did partially block KA-induced toxicity.

It is interesting to note that the absolute increases in $\left[\mathrm{Ca}^{2+}\right]_{\mathrm{i}}$ observed in this study and elsewhere are not that enormous and seldom approach $10^{-6} \mathrm{M}$. One may wonder whether these increases in $\left[\mathrm{Ca}^{2+}\right]_{i}$ are sufficient to produce toxicity, but it should be noted that the increases in $\left[\mathrm{Ca}^{2+}\right]_{i}$ are sustained, which may be an important consideration. Moreover, it has been observed (Marciani et al., 1982; Hamon and Heinemann, 1986) that excitatory amino acids stimulate $\mathrm{Ca}^{2+}$ uptake into both the cell bodies and dendrites of hippocampal neurons. These authors calculated that, although the net uptake of $\mathrm{Ca}^{2}$ observed in the stratum pyrimidale was greater than in the dendritic layers, the absolute concentration of $\mathrm{Ca}^{2+}$ achieved within the dendrites would probably be higher.

Finally, it should be noted that, although we have considered our results in light of the proposed role of $\mathrm{Ca}^{2+}$ in the excitotoxic effects of amino acids, the observed increases in $\left[\mathrm{Ca}^{2+}\right]_{i}$ may normally play a much more important role in phenomena such as long-term potentiation, long-term depression, or other forms of neuronal activity (Lynch and Baudry, 1984; Kano and Kato, 1987).

\section{References}

Anis, N. A., S. C. Berry, N. R. Burton, and D. Lodge (1983) The dissociative anaesthetics ketamine and phencyclidine selectively reduce excitation of central mammalian neurons by $\mathrm{N}$-methyl-aspartate. Br. J. Pharmacol. 79: 565-575.

Ascher, P., and L. Nowak (1986) Calcium permeability of the channels activated by N-methyl-D-aspartate (NMDA) in isolated mouse central neurons. J. Physiol. (Lond.) 377: 35p.

Ashton, D., K. Reid, R. Willems, and A. Wauquier (1986) N-methylD-aspartate and hypoxia induced $\mathrm{Ca}^{2+}$ changes in $\mathrm{CA}$, region of the hippocampal slice. Brain Res. 385: 185-188.

Baker, P. F., and R. DiPolo (1984) Axonal calcium and magnesium homeostasis. Current Topics Memb. Trans. 22: 195-247.

Beal, M. F., N. W. Kowall, D. W. Edison, M. F. Mazurek, K. J. Swartz, and J. M. Martin (1986) Replication of the neurochemical characteristics of Huntington's disease by quinolinic acid. Nature 321: 168-171.

Berdichevsky, E., N. Riveros, S. Sanchez-Armass, and F. Orrego (1983) Kainate, N-methyl-aspartate and other excitatory amino acids increase calcium influx into rat brain cortex cells in vitro. Neurosci. Lett. 36: 75-80. 
Bers, D. M. (1982) A simple method for the accurate determination of free [Ca] in Ca-EGTA solutions. Am. J. Physiol. 242: C404-C 408.

Buhrle, P., and V. Sonnhof (1983) The ionic mechanism of the excitatory action of glutamate upon the membranes of motoneurones of the frog. Pflugers Arch. 396: 154-162.

Choi, D. W. (1985) Glutamate neurotoxicity in cortical cell cultures is calcium dependent. Neurosci. Lett. 58: 293-297.

Choi, D. W. (1987) Ionic dependence of glutamate neurotoxicity. J. Neurosci. 7: 369-379.

Choi, D. W., M. Maulucci-Gidde, and A. R. Kriegstein (1987) Glutamate neurotoxicity in cortical cell culture. J. Neurosci. 7: 357-368.

Crowder, J. M., M. J. Croucher, H. J. Bradford, and J. F. Collins (1986) $\mathrm{N}$-methyl-D-aspartate antagonists inhibit $\mathrm{Ca}^{2+}$ influx into hippocampal slices stimulated by depolarizing agents and by excitatory amino acids. Trans. Biochem. Soc. 14: 910-911.

Crunelli, V., and M. L. Mayer (1984) $\mathbf{M g}^{2+}$ dependence of membrane resistance changes evoked by NMDA in hippocampal neurones. Brain Res. 311: 392-396.

Cull-Candy, S. G., and D. C. Ogden (1985) Ion channels activated by L-glutamate and GABA in cultured cerebellar neurones of the rat. Proc. R. Soc. London [Biol.] 224: 367-373.

Cull-Candy, S. G., and M. M. Usowicz (1987) Multiple conductance channels activated by excitatory amino acids in cerebellar neurones. Nature 325: 525-528.

Ferkany, J. W., R. Zaczek, and J. T. Coyle (1982) Kainic acid stimulates excitatory amino acid neurotransmitter release at presynaptic receptors. Nature 298: 757-759.

Foster, A. C., and G. E. Fagg (1984) Acidic amino acid binding sites in mammalian neuronal membranes: Their characteristics and relationship to synaptic receptors. Brain Res. Rev. 7: 103-164.

Foster, A. C., R. Gill, and J. A. Kemp (1986) Protection of N-methyl$D$-aspartate induced neuronal degeneration by systematic administration of MK801. Br. J. Pharmacol. 89: 870p.

Garthwaite, G., and J. Garthwaite (1986a) Neurotoxicity of excitatory amino acid receptor antagonists in rat cerebellar slices: Dependence on calcium concentration. Neurosci. Lett. 66: 193-198.

Garthwaite, G., and J. Garthwaite (1986b) Amino acid neurotoxicity: Intracellular sites of calcium accumulation associated with the onset of irreversible damage to rat cerebellar neurones in vitro. Neurosci. Lett. 71: 53-58.

Garthwaite, G., F. Hajos, and J. Garthwaite (1986) Ionic requirements for neurotoxic effects of excitatory amino acid analogues in rat cerebellar slices. Neuroscience 18: 437-447.

Hagiwara, S., and L. Byerly (1981) Calcium channels. Annu. Rev. Neurosci. 4: 69-125.

Hajos, F., G. Garthwaite, and J. Garthwaite (1986) Reversible and irreversible neuronal damage caused by excitatory amino acid analogues in rat cerebellar slices. Neuroscience 18: 417-436.

Hamon, B., and V. Heinemann (1986) Effects of GABA and bicuculline on N-methyl-D-aspartate and quisqualate induced reductions in extracellular free calcium in area CA1 of the hippocampal slice. Exp. Brain Res. 64: 27-36.

Harris, R. A. (1985) Effects of excitatory amino acids on calcium transport by brain membranes. Brain Res. 337: 167-170.

Heinemann, U., and R. Pumain (1980) Extracellular calcium activity changes in cat sensorimotor cortex induced by iontophoretic application of amino acids. Exp. Brain Res. 40: 247-250.

Heinemann, U., and R. Pumain (1981) Effects of tetrodotoxin on changes in extracellular free calcium induced by repetitive electrical stimulation and iontophoretic application of excitatory amino acids in the sensorimotor cortex of cats. Neurosci. Lett. 21: 87-91.

Heinemann, U., B. Hamon, and A. Konnerth (1984) GABA and bacloten reduce changes in extracellular free calcium in the area CA1 of rat hippocampal slices. Neurosci. Lett. 47: 295-300.

Honey, C. R., Z. Miljkovic, and J. F. MacDonald (1985) Ketamine and phencyclidine cause a voltage dependent block of responses to L-aspartic acid. Neurosci. Lett. 61: 135-139.

Ichida, S., H. Tokunaga, M. Moriyama, Y. Oda, S. Tanaka, and T. Kita (1982) Effects of neurotransmitter candidates on ${ }^{45} \mathrm{Ca}^{2+}$ uptake by cortical slices of rat brain: Stimulatory effect of $L$-glutamic acid. Brain Res. 248: 305-311.

Jahr, C. E., and C. F. Stevens (1987) Glutamate activates multiple single channel conductances in hippocampal neurones. Nature 325 : 522-525.

Kano, M., and M. Kato (1987) Quisqualate receptors are specifically involved in cerebellar synaptic plasticity. Nature 325: 276-278.
Kleinschmidt, J., C. L. Zucker, and S. Yazulla (1986) Neurotoxic action of kainic acid in isolated toad and goldfish retina. II. Mechanism of action. J. Comp. Neurol. 254: 196-208.

Korf, J., and F. Postema (1984) Regional calcium accumulation and cation shifts in rat brain by kainate. J. Neurochem. 43: 1052-1060.

Kudo, Y., and A. Ogura. (1986) Glutamate induced increase in intraccllular $\mathrm{Ca}^{7+}$ concentration in isolated hippocampal ncuroncs. $\mathrm{Br}$. J. Pharmacol. 89: 191-199.

Lazarewicz, J. W., A. Lehmann, H. Hagberg, and A. Hamberger (1986) Effects of kainic acid on brain calcium fluxes studied in vivo and in vitro. J. Neurochem. 46: 494-498.

Lynch, G., and M. Baudry (1984) The biochemistry of memory: A new specific hypothesis. Science 224: 1057-1063.

MacDermott, A., and F. Weight (1982) Action potential repolarization may involve a transient $\mathrm{Ca}^{2+}$ sensitive outward current in a vertebrate neurone. Nature 300: 185-188.

MacDermott, A., M. L. Mayer, G. L. Westbrook, S. J. Smith, and J. C. Barker (1986) NMDA receptor activation increases cytoplasmic calcium concentration in cultured spinal cord neurones. Nature 321 : 519-522.

Marciani, M. G., J. Louvel, and U. Heinemann (1982) Aspartate induced changes in extracellular free calcium "in vitro" hippocampal slices of rats. Brain Res. 238: 272-277.

Mayer, M. L., and G. L. Westbrook (1984) Mixed agonist action of excitatory amino acids in voltage clamped mouse spinal neurones. $J$. Physiol. (Lond.) 354: 29-53.

Mayer, M. L., and G. L. Westbrook (1985a) Divalent cation permeability of the N-methyl-D-aspartate channel. Soc. Neurosci. Abstr. 11: 785 .

Mayer, M. L., and G. L. Westbrook (1985b) The action of N-methylD-aspartic acid on mouse spinal neurones in culture. J. Physiol. (Lond.) 361: 65-90.

Mayer, M. L., and G. L. Westbrook (1987a) The physiology of excitatory amino acids in the vertebrate central nervous system. Prog. Neurobiol. 28: 197-276.

Mayer, M. L., and G. L. Westbrook (1987b) Permeation and block of N-methyl-D-aspartic acid receptor channels by divalent cations in mouse central neurones. J. Physiol. (Lond.) (in press).

Mayer, M. L., G. L. Westbrook, and P. B. Guthrie (1984) Voltage dependent block by $\mathrm{Mg}^{2+}$ of NMDA responses in spinal cord neurones. Nature 309: 261-263.

Mayer, M. L., A. B. MacDermott, G. L. Westbrook, S. I. Smith, and J. L. Barker (1987) Agonist- and voltage-gated calcium entry in cultured mouse spinal cord neurons under voltage clamp measured using arsenazo III. J. Neurosci. 7: 3230-3244.

Murphy, D. E., J. Schneider, C. Boehm, J. Lehmann, and M. Williams (1987) Binding of $\left[{ }^{3} \mathrm{H}\right]$ CPP (3-(2-carboxypiperazin-4-yl) propyl-1phosphonic acid) to ral brain membranes: A selective high aflinity ligand for N-methyl-D-aspartate receptors. J. Pharmacol. Exp. Ther. 240: 737-746.

Neering, I. R., and R. W. McBurney (1984) Role for microsomal $\mathrm{Ca}^{2+}$ storage in mammalian neurones. Nature 309: 158-160.

Nicoletti, F., M. J. Iadarola, J. T. Wroblewski, and E. Costa (1986a) Excitatory amino acids recognition sites coupled with inositol phospholipid metabolism: Developmental changes and interaction with 1-receptors. Proc. Natl. Acad. Sci. USA 83: 1931-1935.

Nicoletti, F., J. T. Wroblewski, H. Alho, and E. Costa (1986b) Stimulation of inositol phospholipid hydrolysis by excitatory amino acids in rat brain: Enhanced sensitivity during the development or after specific lesions of glutaminergic pathways. Soc. Neurosci. Abstr. 12: 380 .

Nicoletti, F., J. T. Wrobelewski, and E. Costa (1987) Magnesium ions inhibit the stimulation of inositol phospholipid hydrolysis by endogenous excitatory amino acids in primary cultures of cerebellar granule cells. J. Neurochem. 48: 967-973.

Nowak, L. M., and P. Ascher (1984) N-methyl-D-aspartate, kainic and quisqualic acids evoke currents in mammalian central neurones. Soc. Neurosci. Abstr. 10: 23.

Nowak, L. M., and P. Ascher (1985) Divalent cation effects on NMDA activated channels can be described as $\mathrm{Mg}$ like or Ca like. Soc. Neurosci. Abstr. 11: 953.

Nowak, L. M., P. Bregestovski, P. Ascher, A. Herbert, and A. Prochiantz (1984) Magnesium gates glutamate activated channels in mouse central neurones. Nature 307: 462-465.

Nowycky, M. C., A. P. Fox, and R. W. Tsien (1985) Three types of 
neuronal calcium channels with different calcium agonist sensitivity. Nature 316: 440-443.

O'Brien, R. J., and G. D. Fischbach (1986) Characterization of excitatory amino acid receptors expressed by embryonic chick motoneurones in vitro. J. Neurosci. $6: 3275-3283$.

Olney, J. W. (1969) Glutamate induced retinal degeneration in neonatal mice. Electron microscopy of the acutely evolving lesion. $J$. Neuropathol. Exp. Neurol. 28: 455-474.

Olney, J. W., M. T. Price, T. A. Fuller, J. Labruyere, L. Samson, M. Carpenter, and K. Mahan (1986) The antiexcitotoxic effects of certain anaesthetics, analgesics and sedative hypnotics. Neurosci. Lett. 68: 29-34.

Olverman, H. J., D. T. Monaghan, C. W. Cotman, and J. C. Watkins (1986) $\left[{ }^{3} \mathrm{H}\right] \mathrm{CPP}$, a new competitive ligand for NMDA receptors. Eur. J. Pharmacol. 131: 161-162.

Panula, P., P. Emson, and J.-Y. Wu (1980) Demonstration of enkephalin, substance $P$ and glutamate decarboxylase like immonoreactivity in cultured cells divided from newborn rat striatum. Histochemistry 69: 169-179.

Pastuszko, A., and D. F. Wilson (1985) Kainate induced uptake of calcium by synaptosomes from rat brain. FEBS. Lett. 192: 61-65.

Perney, T., R. Dinerstein, and R. J. Miller (1984) Depolarization induced increases in intracellular free calcium detected in single cultured neuronal cells. Neurosci. Lett. 51: 165-170.

Price, M. T., J. W. Olney, L. Samson, and J. Labruyere (1985) Calcium influx accompanies but does not cause excitoxin induced neuronal necrosis in retina. Brain Res. Bull. 14: 369-376.

Pumain, R., and U. Heinemann (1985) Stimulus and amino acid induced calcium and potassium changes in rat neocortex. J. Neurochem. 53:1-15.

Retz, K. C., and J. T. Coyle (1984) The differential effects of excitatory amino acids or uptake of ${ }^{45} \mathrm{CaCl}_{2}$ by slices from mouse striatum. Neuropharmacology 23: 89-94.

Retz, K. C., A. L. Young, and J. T. Coyle (1982) Glutamate stimulation of ${ }^{45} \mathrm{Ca}^{2+}$ uptake by rat striatal synaptosomes. Eur. J. Pharmacol. 79. 319-322.

Riveros, S. N., and F. Orrego (1986) N-methyl-aspartate activated calcium channels in rat brain cortical slices. Effect of calcium channel blockers and of inhibitory and depressant substances. Neuroscience 17: $541-546$.

Rothman, S. M. (1985) The neurotoxicity of excitatory amino acids is produced by passive chloride influx. J. Neurosci. 5: 1483-1489.

Rothman, S. M., and M. Samaie (1985) Physiology of excitatory syn- aptic transmission in cultures of dissociated rat hippocampus. J. Neurophysiol. 54: 701-713.

Saida, K., and C. VanBreemen (1984) Characteristics of the norepinephrine sensitive $\mathrm{Ca}^{2+}$ homeostasis in vascular smooth muscle. Blood Vessels 21: 43-52.

Sakamoto, N., K. Kogure, H. Kato, and H. Ohtomo (1986) Disturbed $\mathrm{Ca}^{2+}$ homeostasis in the gerbil hippocampus following brief transient ischemia. Brain Res. 364: 372-376.

Schwarcz, R., A. C. Foster, E. D. French, W. O. Whetsell, and C. Kohler (1984) Excitotoxic models for neurodegenerative disorders. Life Sci. 35: $19-32$.

Shen, A. C., and R. B. Jennings (1972) Myocardial calcium and magnesium in acute ischemic injury. Am. J. Physiol. 67: 441-452.

Silverstein, F. S., R. Chen, and M. U. Johnston (1986) The glutamate analogue quisqualic acid is neurotoxic in striatum and hippocampus of immature rat brain. Neurosci. Lett. 71: 13-18.

Smith, S. J., A. B. MacDermott, and F. F. Weight (1983) Detection of intracellular $\mathrm{Ca}^{2+}$ transients in sympathetic neurones using arsenazo III. Nature 304: 350-352.

Sugiyama, H., I. Ito, and C. Hirono (1987) A new type of glutamate receptor linked to inositol phosholipid metabolism. Nature $325: 531-$ 533.

Thayer, S. A., S. N. Murphy, and R. J. Miller (1986) Widespread distribution of dihydropyridine sensitive calcium channels in the central nervous system. Mol. Pharmacol. 30: 305-309.

Westbrook, G. L., and M. L. Mayer (1984) Glutamate currents in mammalian spinal neurones: Resolution of paradox. Rrain Res. 301: 375-379.

Wong, E. H. F., J. A. Kemp, T. Priestly, A. R. Knight, G. N. Woodruff, and $L$. L. Iversen (1986) The novel anticonvulsant MK-801 is a potent N-methyl-D-aspartate antagonist. Proc. Natl. Acad. Sci. USA 83: 7104-7108.

Wroblewski, J. T., F. Nicoletti, and E. Costa (1985) Different coupling of excitatory amino acid receptors with $\mathrm{Ca}^{2+}$ channels in primary cultures of cerebellar granule cells. Neuropharmacology 24:919-921.

Wroblewski, J. T., F. Nicoletti, and E. Costa (1987) Excitatory amino acid receptors in primary cultures of cerebellar granule cells: Two signals transducing mechanisms in receptor modulated $\mathrm{Ca}$ influx. J. Neurochem. (in press).

Zanotto, L., and U. Heinemann (1983) Aspartate and glutamate induced reductions in extracellular free calcium and sodium concentration in area CAl of "in vitro" hippocampal slice of rats. Neurosci. Lett. 35: 79-84. 